DANIELA DE ALCANTARA LEITE DOS REIS

Avaliação comparativa dos detalhes anatômicos dos ossos do membro torácico do equino e de seus biomodelos produzidos por digitalização e impressão 3D

São Paulo 


\title{
Avaliação comparativa dos detalhes anatômicos dos ossos do membro torácico do equino e de seus biomodelos produzidos por digitalização e impressão 3D
}

\begin{abstract}
Dissertação apresentada ao Programa de PósGraduação em Anatomia dos Animais Domésticos e Silvestres da Faculdade de Medicina Veterinária e Zootecnia da Universidade de São Paulo para a obtenção do título de Mestre em Ciências.
\end{abstract}

\section{Departamento:}

Departamento de Cirurgia

Área de concentração:

Anatomia dos Animais Domésticos e Silvestres

Orientador:

Prof. Dr. Antônio Chaves de Assis Neto

De acordo:

Orientador

São Paulo 
Autorizo a reprodução parcial ou total desta obra, para fins acadêmicos, desde que citada a fonte.

\section{DADOS INTERNACIONAIS DE CATALOGAÇÃO NA PUBLICAÇÃO}

(Biblioteca Virginie Buff D’Ápice da Faculdade de Medicina Veterinária e Zootecnia da Universidade de São Paulo)

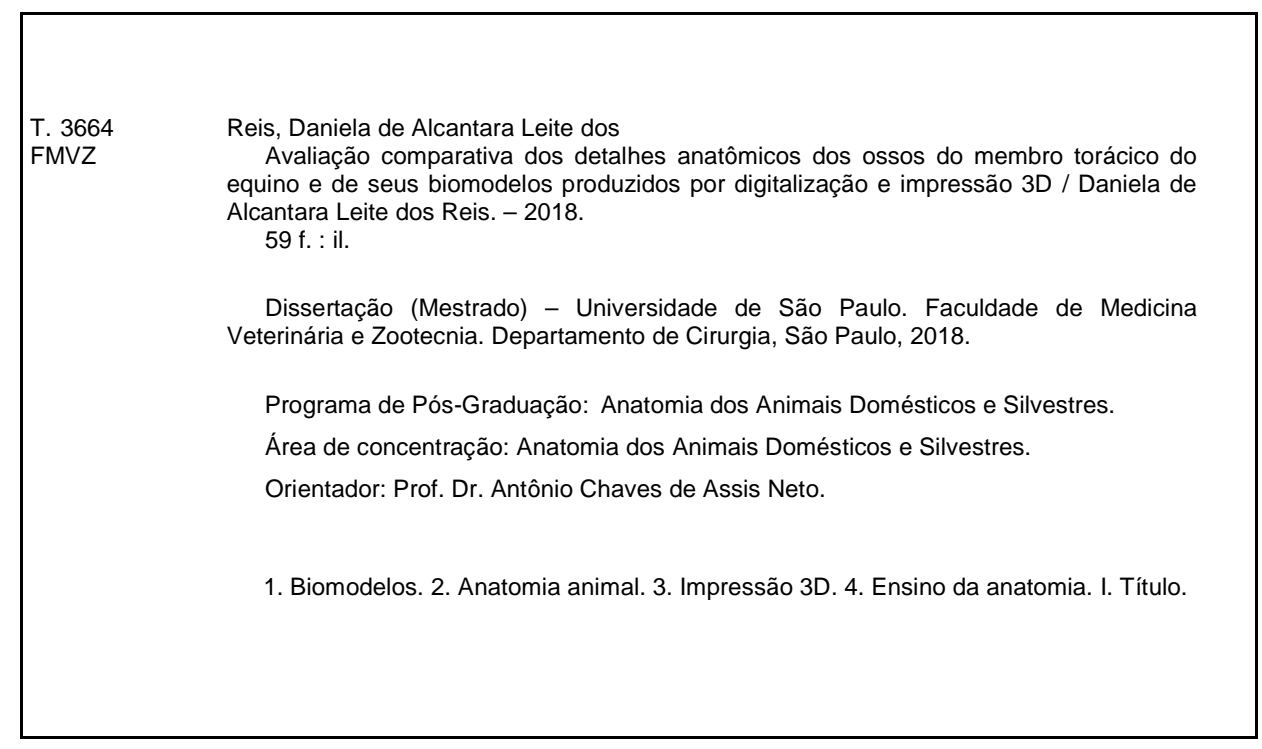

Ficha catalográfica elaborada pela bibliotecária Maria Aparecida Laet, CRB 5673-8, da FMVZ/USP. 


\section{ERRATA}

REIS, D. A. L. Avaliação comparativa dos detalhes anatômicos dos ossos do membro torácico do equino e de seus biomodelos produzidos por digitalização e impressão 3D. 2018. 58 f. Dissertação (Mestrado em Ciências) - Faculdade de Medicina Veterinária e Zootecnia, Universidade de São Paulo, São Paulo, 2018.
Folha
Parágrafo
Linha
Onde se lê
Leia-se

Ficha catalográfica $3^{\circ}$

1 a $\quad 59 \mathrm{f}$.

$58 \mathrm{f}$. 
Imolai snial.

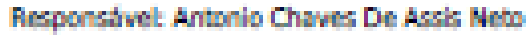

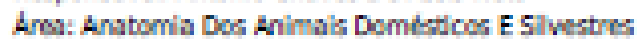

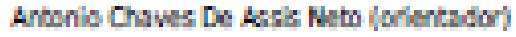

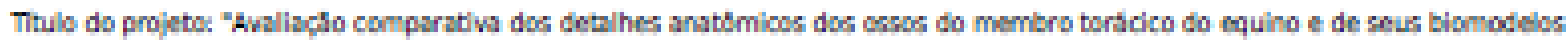
producidor por dig tallachlo e imprestio 90.".

\section{Farecer Contubstanciado da CEUA FMVzUSP}

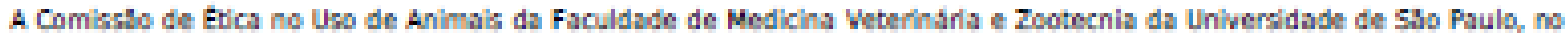

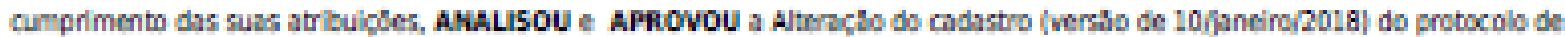
ctudo achan menenciada.

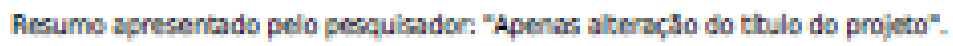

Comention de clis:

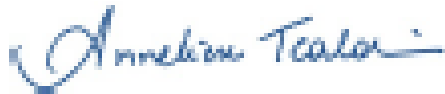

Proth. Dra. Annilose de Sourn Trald

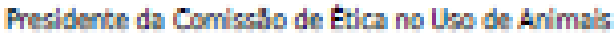

Faculdada de Hodicha Heterintirla a Zootecria do Uniwersidade de Sto Failo

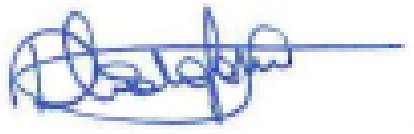

Fuestida Corta Gomes

Sonthis Exmotiv

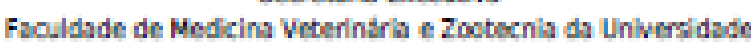
do Sho Paulo 
FOLHA DE AVALIAÇÃO

Autor: REIS, Daniela de Alcantara Leite dos

Título: Avaliação comparativa dos detalhes anatômicos dos ossos do membro torácico do equino e de seus biomodelos produzidos por digitalização e impressão 3D

Dissertação apresentada ao Programa de PósGraduação em Anatomia dos Animais Domésticos e Silvestres da Faculdade de Medicina Veterinária e Zootecnia da Universidade de São Paulo para a obtenção do título de Mestre em Ciências.

Data:

Banca Examinadora

Prof. Dr.

Instituição: Julgamento:

Prof. Dr. Instituição: Julgamento:

Prof. Dr. Instituição: Julgamento: 


\section{DEDICATÓRIA}

Dedico essa dissertação aos meus queridos pais, em especial à minha mãe, que sempre esteve ao meu lado me apoiando; aos meus irmãos queridos que tornam

todos os momentos da minha vida sempre mais fáceis e divertidos e principalmente ao meu companheiro que divide comigo os meus sonhos, me apoia incondicionalmente e me faz enxergar sempre o melhor em tudo. 


\section{AGRADECIMENTOS}

Ao Programa de Pós Graduação em Anatomia dos Animais Domésticos e Silvestres da Faculdade de Medicina Veterinária e Zootecnia da Universidade de São Paulo pela oportunidade.

A todos os professores do Programa de Pó-Graduação em Anatomia dos Animais Domésticos e Silvestres da FMVZ-USP pelos valiosos ensinamentos transmitidos durante as aulas da pós- graduação.

Ao meu orientador Prof. Dr. Antônio Chaves de Assis Neto que me acolheu, obrigada pela confiança, paciência e atenção durante todo o período de convivência para a realização desse mestrado.

A todos os alunos de Iniciação Científica, pela participação e auxílio no desenvolvimento desse projeto de pesquisa, colaborando de forma relevante.

Aos colegas de pós-graduação agradeço a ajuda e convivência durante todo o tempo de desenvolvimento desse trabalho.

Aos funcionários do Programa de Pó-Graduação em Anatomia dos Animais Domésticos e Silvestres pela ajuda recebida durante o curso.

A CAPES por viabilizar recursos para a realização do curso de Mestrado em Anatomia dos Animais Domésticos e Silvestres.

Aos amigos Delys e Rodrigo, pessoas com as quais eu verdadeiramente pude contar durante o curso, pelo apoio incondicional em todos os momentos, enriquecendo a experiência vivida nesse programa de pós-graduação.

Ao amigo Prof.Dr. Marcos pela grandiosa contribuição na minha vida profissional me indicando e incentivando não só para a realização do mestrado como também para a realização de outros projetos profissionais. 
Meus agradecimentos pela contribuição da banca no exame de qualificação e pela participação dos membros da banca examinadora da defesa

Ao meu companheiro Davi, sempre presente ao meu lado me impulsionando e contribuindo de forma ímpar para a realização dos meus sonhos. 
"Só por que alguma coisa não faz o que você planejou que ela fizesse não quer dizer que ela seja inútil". Thomas Edison 


\section{RESUMO}

REIS, D. A. L. Avaliação comparativa dos detalhes anatômicos dos ossos do membro torácico do equino e de seus biomodelos produzidos por digitalização e impressão 3D. [Comparative assessment of anatomical details of equines' thoracic limb bones and its biomodels produced via scanning and 3D printing]. 2018. 59 f. Dissertação (Mestrado em Ciências) - Faculdade de Medicina Veterinária e Zootecnia, Universidade de São Paulo, São Paulo, 2018.

O uso da digitalização e da impressão tridimensional (3D) com a produção de biomodelos que possam ser usados em aulas práticas das disciplinas de anatomia veterinária no Brasil é uma ferramenta inovadora. O acesso dos alunos a essa material didático pode representar um aspecto importante no aprendizado da anatomia de animais domésticos. Neste estudo, foi utilizado um scanner que faz a captura tridimensional das imagens e uma impressora 3D que realiza a impressão por deposição de material fundido (FDM) para produzir modelos esqueléticos de do membro torácico do equino. Foram usados a escápula, o úmero, radio e ulna, ossos do carpo e falanges usada para produzir modelos digitais. Estes foram então usados para produzir modelos físicos através da impressão, realizada em várias escalas. As características anatômicas dos modelos impressos tridimensionais (3D) foram então comparadas com as dos ossos do esqueleto original. Os resultados deste estudo demonstraram que os biomodelos de animais podem ser rapidamente produzidos usando a tecnologia de impressão 3D. Em termos de precisão entre os biomodelos e as peças anatômicas originais não houve diferença significativa na estatística. Todas as características, exceto o forame nutrício, puderam ser identificadas nas cópias impressas em 3D.

Palavras-chave: biomodelos, anatomia animal, impressão 3D, ensino da anatomia. 


\begin{abstract}
REIS, D. A. L. Comparative assessment of anatomical details of equines' thoracic limb bones and its biomodels produced via scanning and 3D printing. [Avaliação comparativa dos detalhes anatômicos dos ossos do membro torácico do equino e de seus biomodelos produzidos por digitalização e impressão 3D]. 2018. 59 f. Dissertação (Mestrado em Ciências) - Faculdade de Medicina Veterinária e Zootecnia, Universidade de São Paulo, São Paulo, 2018.
\end{abstract}

The use of three-dimensional (3D) scanning and printing for the production of biomodels that can be used in practical classes of veterinary anatomy disciplines in Brazil is an innovative tool. The students' ease of access to this teaching material can be an important aspect of learning the anatomy of domestic animals. In this study, a scanner was used to capture three-dimensional images and a 3D printer that performs die-cast printing (FDM) was used to produce skeletal models of equines' thoracic limb. The scapula, humerus, radius and ulna, carpal bones and phalanges were used to produce digital models and physical models for 3D impressions. The anatomical characteristics of the three-dimensional printed models were then compared with those of the original skeletal bones. The results of this study demonstrated that animal biomodels can be rapidly produced using 3D printing technology. In terms of precision between the biomodels and the original anatomical parts, there was no significant statistical difference. All the characteristics, except for the foramen nutritium, were successfully identified in the 3D printed copies.

Keywords: biomodel, animal anatomy, 3D printing, anatomy education. 


\section{LISTA DE FIGURAS}

Figura 1 - Princípio de funcionamento de uma impressora 3D FDM ......................22

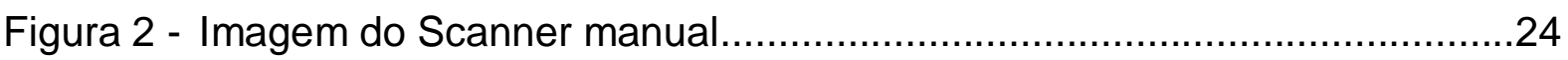

Figura 3- Imagens digitalizadas e editadas dos ossos do membro torácico do equino. Software Geomagic ${ }^{\circledR}$.

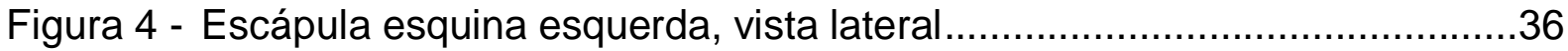

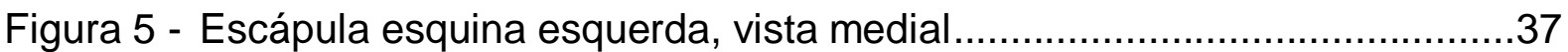

Figura 6 - Escápula esquina esquerda, destaque para cavidade glenoide e tubérculo supraglenoidal.

Figura 7 - Biomodelo impresso em 3D do úmero equino, vista cauda $(A)$ e vista lateral (B). 38

Figura 8- Biomodelo impresso em 3D do da extremidade proximal úmero equino (A) e úmero equino $(\mathrm{B})$, vista cranial .39

Figura 9 - Biomodelo impresso em 3D do da extremidade distal úmero equino $(A)$ e úmero equino $(B)$

Figura 10 - Biomodelo impresso em 3D do da extremidade distal equino, vista caudal

Figura 11 - Biomodelo impresso em 3D do radio e ulna do equino $(A)$ e osso radio e ulna esquerdos do equino (B), vista lateral

Figura 12 - Extremidade proximal do biomodelo impresso em 3D do radio e ulna do equino $(A)$ e osso radio e ulna esquerdos do equino $(B)$, vista lateral

Figura 13 - Extremidade proximal do biomodelo impresso em 3D do radio e ulna do equino e osso radio e ulna esquerdos do equino, vista cranial $(A)$ e caudal $(B) \ldots . . .43$ Figura 14 - Extremidade proximal do biomodelo impresso em 3D do radio do equino (A) e osso radio esquerdo do equino (B), vista caudal.

Figura 15 - Biomodelo impresso em 3D dos ossos metacarpianos (A) e ossos metacarpianos esquerdos do equino (B), vista palmar

Figura 16- Extremidade proximal (A) e extremidade distal (B) do biomodelo impresso em 3D dos ossos metacarpianos e ossos metacarpianos esquerdos do equino, vista palmar.

Figura 17 - Extremidade proximal do biomodelo impresso em 3D dos ossos metacarpianos e ossos metacarpianos esquerdos do equino, vista dorsal...... 
Figura 18 -Ossos do carpo do membro torácico esquerdo do equino (A) e seus biomodelos impressos por impressão 3D (B)...................................................47

Figura 19 -Biomodelo impresso em 3D dos da falange proximal, falange média, falange distal e ossos sesamoide distal (A) e ossos proximal, falange média, falange distal e sesamoide distal esquerdos do equino $(B)$, vista dorsal............................48 Figura 20 -Biomodelos impressos em 3D e ossos da falange proximal, falange media na vista dorsal e palmar e falange distal do equino vista dorsal. .49 


\section{LISTA DE TABELAS}

Tabela 1 - Tempo de impressão dos modelos 3D, quantidade de material usado na impressão da peça e quantidade de material de suporte utilizado em cada impressão .28

Tabela 2 - Valores comparativos entre os pesos dos ossos e dos modelos

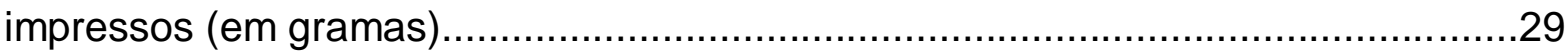

Tabela 3 - Custo com material para impressão dos biomodelos. .29

Tabela 4 - Medidas das estruturas anatômicas na escápula e no biomodelo impresso

Tabela 5 - Medidas das estruturas anatômicas no úmero e no biomodelo impresso

Tabela 6 - Medidas das estruturas anatômicas no rádio e na ulna e no biomodelo impresso

Tabela 7 - Medidas das estruturas anatômicas nos ossos metacarpianos (II, II e IV) e no biomodelo impresso 32

Tabela 8 - Medidas das estruturas anatômicas na falange proximal e no biomodelo impresso .33

Tabela 9 - Medidas das estruturas anatômicas na falange média e no biomodelo impresso

Tabela 10 - Medidas das estruturas anatômicas na falange distal e no biomodelo impresso

Tabela 11 - Tabela 11: Medidas das estruturas anatômicas dos ossos do carpo e nos biomodelos impressos. 


\section{SUMÁRIO}

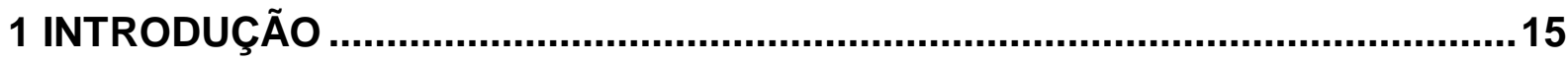

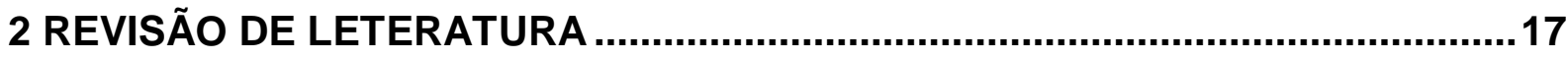

2.1 USO DA IMPRESSÃO TRIDIMENSIONAL NA ÁREA DA SAÚDE E ENSINO ...........17

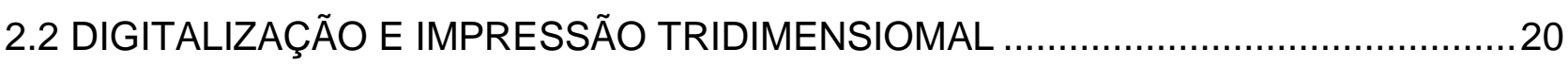

2.2.1 Digitalização a Laser por Triangulação ...............................................20

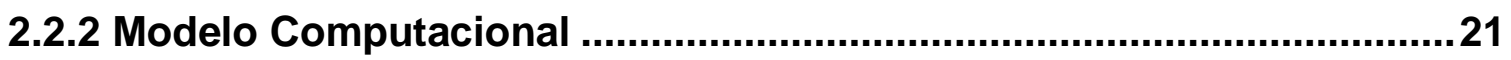

2.2.3 Impressão Tridimensional 3D-Sistema FDM (Fusion Deposition

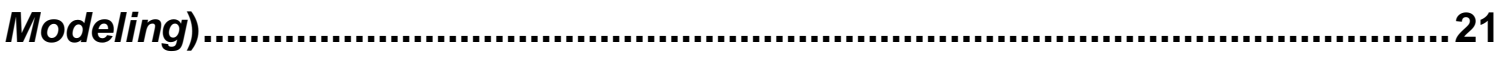

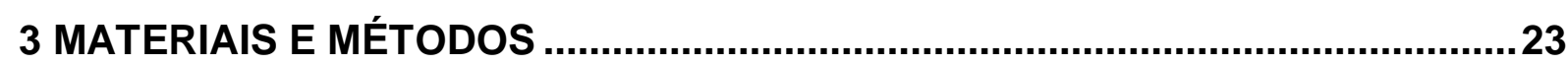

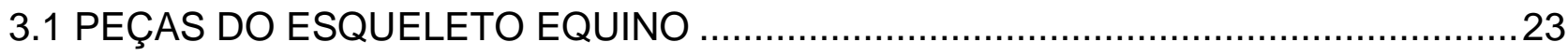

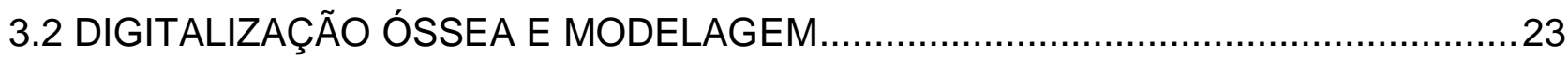

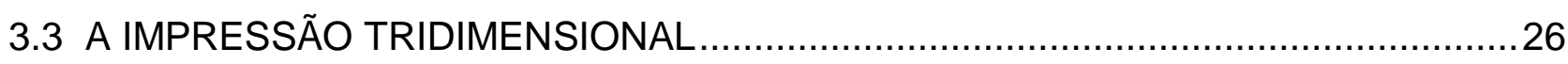

3.4 ANÁLISES COMPARATIVAS DOS OSSOS E BIOMODELOS ................................26

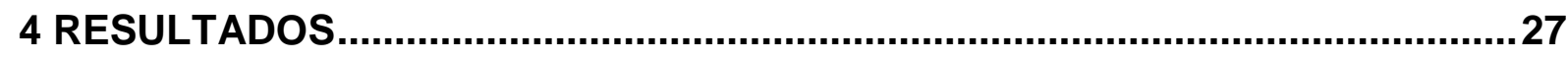

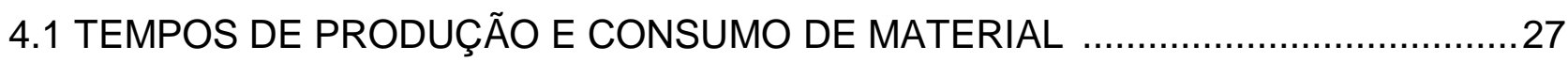

4.1.1 Comparação entre o peso dos ossos e os modelos impressos .........28

4.2 CUSTOS APROXIMADOS DE CADA PEÇA PRODUZIDA …................................29

4.3 COMPARAÇÕES DOS DETALHES ANATÔMICOS …......................................... 30

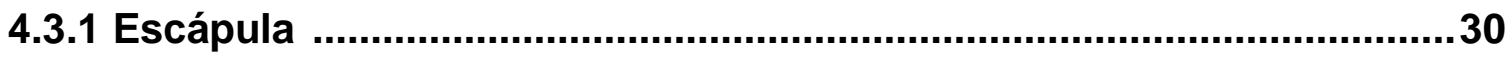

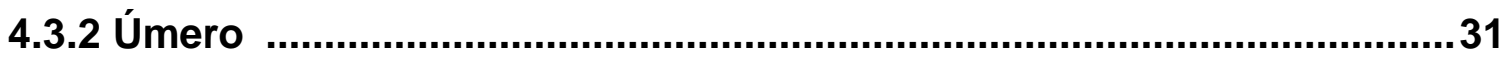

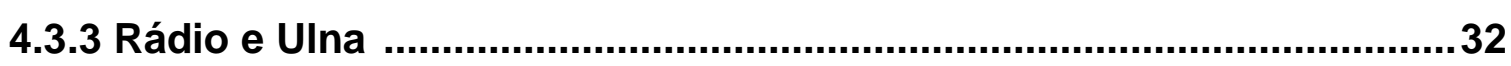

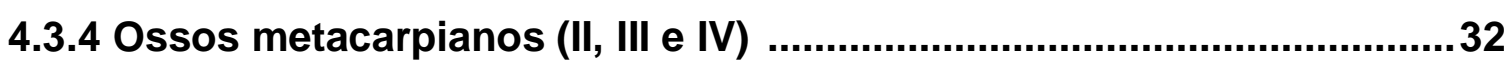

4.3.5 Falanges (Proximal, média e distal) ……................................................ 33

4.3.6 Ossos do Carpo e sesamoide distal ...................................................... 34

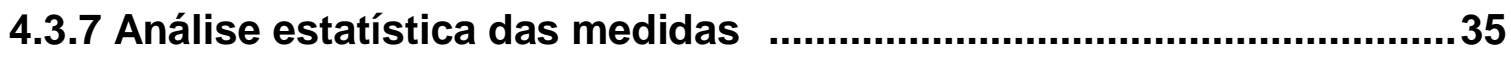

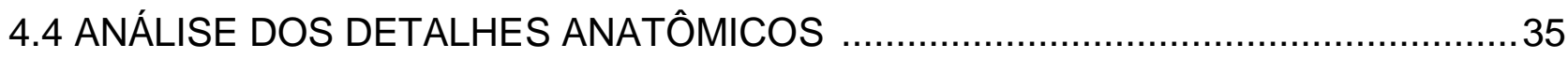


4.4.1 Características anatômicas do modelo impresso 3D da Escápula ....35

4.4.2 Características anatômicas do modelo impresso 3D do Úmero .........38

4.4.3 Características anatômicas do modelo impresso 3D do Rádio e Ulna

4.4.4 Características anatômicas do modelo impresso 3D dos Ossos

Metacarpianos

4.4.5 Características anatômicas do modelo impresso 3D dos Ossos do Carpo 46

4.1.6 Características anatômicas do modelo impresso 3D das Falanges ...48

5 DISCUSSÃO .50

5.1 SUGESTÕES PARA TRABALHOS FUTUROS 53

6 CONCLUSÕES .54

REFERÊNCIAS .55 


\section{INTRODUÇÃo}

A anatomia é a ciência que estuda macro e microscopicamente a morfologia do corpo, cabendo a ela a nomenclatura e descrição de todas as estruturas deste (Dangelo\& Fattini 2007). O ensino teórico da anatomia é de extrema importância, mas a prática é indispensável para a consolidação do aprendizado teórico. É através da prática utilizando-se geralmente como materiais didáticos peças anatômicas de cadáveres formolizados que o aluno irá, no laboratório, utilizar os conhecimentos teóricos e relacioná-los com as estruturas observadas nas peças anatômicas. E para que essa prática seja bem sucedida é importante que a peça anatômica utilizada esteja em bom estado de conservação apresentando cor, textura, flexibilidade e outras características o mais próximo possível do que se encontraria em um ser vivo.

Atualmente muitos recursos tecnológicos estão inseridos no cotidiano do aluno, esses recursos, portanto, podem ser aplicados no ensino, com o desenvolvimento de métodos de ensino interativos que auxiliem no ensino e aprendizagem fazendo com que o aluno se sinta cada vez mais estimulado a adquirir conhecimento.

Vários métodos de ensino estão disponíveis atualmente para o uso no ensino da medicina veterinária, tais como: simuladores computadorizados, softwares, aplicativos, vídeos interativos, filmes, manequins mecânicos, realidade virtual, modelos plásticos e lou de borrachas e modelos plastinados (GEBARA, 2015). A digitalização e a impressão tridimensional (3D) pode vir agregar como mais um método auxiliar de ensino.

$\mathrm{Na}$ área médica a impressão tridimensional de órgãos já é bastante empregada no diagnóstico e planejamento cirúrgico e dentre os benefícios encontrados na literatura referente ao seu uso estão: a redução do tempo de realização dos procedimentos operatórios, redução do período de anestesia, do risco de infecção e o número de cirurgias necessárias para obtenção do resultado final, além do custo total do tratamento (HESPEL; WILHITE; HUDSON, 2014).

Atualmente, em algumas universidades, muitas aulas de anatomia são ministradas através de softwares de anatomia que mimetizam, com a tecnologia 3D, várias espécies animais. Modelos tridimensionais feitos de resina plástica rígida ou maleável fornecem experiência tátil e espacial, que não é possível de se obter 
somente usando os softwares de ensino, e podem ser usados como complemento às aulas (GEBARA, 2015).

Outras técnicas podem ser usadas para reconstruir modelos digitais, com 0 uso exames de imagem como ressonância magnética, raios- $X$ de alta resolução e tomografia computadorizada (LI et al., 2017). No entanto, esses métodos de imagem podem apresentar um custo elevado e demandam um maior tempo para a aquisição das imagens.

Os scanners que fazem a captura tridimensional das imagens possuem uma capacidade para coletar dados rapidamente, de forma não invasiva e de baixo custo (Ll et al., 2017).

Como consequência do processo de digitalização é possível produzir uma coleção com os arquivos digitais das peças digitalizadas que também poderá ser utilizada nas aulas práticas de anatomia.

A aplicação da digitalização e da impressão tridimensional (3D) com a produção de biomodelos produzidos que possam futuramente ser usados em aulas práticas das disciplinas de anatomia veterinária no Brasil é uma ferramenta inovadora. No presente trabalho foram utilizados processos de digitalização e impressão 3D para a produção de biomodelos (réplicas) de ossos do membro torácico da espécie equina e realizada uma análise comparativa dos detalhes anatômicos entre as réplicas e os ossos, para comprovar se as características visuais apresentadas pelas cópias se aproximam dos ossos originais para futuramente serem utilizados como exemplares para estudos anatômicos. 


\section{REVISÃO DE LITERATURA}

\subsection{USO DA IMPRESSÃO TRIDIMENSIONAL NA ÁREA DA SAÚDE E ENSINO}

Uso de impressão 3D na ciência já vem sendo empregado há alguns anos. Melhorias sucessivas em softwares usados na produção das modelagens 3D e nas impressoras utilizadas para a realização das impressões tridimensionais fizeram com que diversas áreas da saúde como a medicina e odontologia fizessem o uso progressivo dessa tecnologia inovadora (SEARS et al., 2016).

Assim como na medicina humana, a medicina veterinária também vem empregando técnicas de impressão tridimensional (3D) no planejamento cirúrgico. Alguns modelos tridimensionais produzidos foram usados por neurocirurgiões para ajudá-los a preparar a cirurgia da subluxação atlanto-axial em cães de raças miniatura, onde a colocação das placas cirúrgicas é um processo complexo. (HESPEL; WILHITE; HUDSON, 2014).

A biomodelagem é um termo que denomina a reprodução das características morfológicas de uma estrutura anatômica em um modelo físico e o biomodelo é o produto desse processo de reprodução física, que pode ser dividido em duas etapas principais: biomodelagem virtual e biomodelagem física ou prototipagem (SILVA; ROSADO, 2014). A biomodelagem virtual é a etapa responsável pela criação e manipulação de um modelo digital, aprimorando a imagem obtida através de softwares específicos, já a biomodelagem física, ou prototipagem, é a etapa responsável pela obtenção de um modelo físico, através do uso de uma impressora, que faz impressões tridimensionais (3D) (GRANDE NETO, 2016).

Considerando o uso dessa tecnologia no ensino alguns estudos revelam que há uma melhora no aprendizado na formação médica quando associada às técnicas convencionais de ensino em anatomia e patologia com o uso de tecnologias $3 D$ (SILVA; ROSADO, 2014).

Os biomodelos muitas vezes vêm sendo utilizados como instrumentos para o auxílio didático. Anomalias raras podem ser confeccionadas através de biomodelos e futuramente serem utilizadas como uma biblioteca física de casos (GRANDE NETO, 2016). 
A criação dessas réplicas com a técnica de impressão 3D também pode ser bastante útil em algumas disciplinas do curso de medicina veterinária. Em uma universidade norte americana foram impressos modelos de árvore brônquica de um lagarto (Varanus exhantematicus) e de um Crocodilo do Nilo (Crocodylus niloticus) para ilustrar o fluxo de ar nas vias aéreas nesses animais (HESPEL; WILHITE; HUDSON, 2014).

Os modelos de árvore brônquica de um felino e um canino saudável também foram impressas em 3D para o uso no estudo de endoscopia das vias aéreas superiores, ilustrando assim pontos de referência importantes e servindo como uma ferramenta de ensino para os alunos observarem os procedimentos (HESPEL; WILHITE; HUDSON, 2014).

Um estudo realizado em um curso de medicina veterinária demonstrou a importância de modelos 3D para melhorar a experiência no aprendizado dos estudantes de graduação. Este estudo comparou a eficácia de livros de texto, modelos computadorizados e modelos 3D impressos. Os estudantes que usaram modelos 3D tiveram uma melhor experiência de aprendizagem do que aqueles que utilizaram modelos digitais ou livros. Sugerindo então que os modelos 3D melhoram a compreensão das estruturas anatômicas (HESPEL; WILHITE; HUDSON, 2014).

O estudo anatômico de animais raros ou em extinção também pode ser realizado através do uso de modelos $3 \mathrm{D}$, com mínima exposição do animal em questão para a criação do modelo (HESPEL; WILHITE; HUDSON, 2014).

O curso de veterinária de uma universidade na Escócia usou a técnica de modelagem 3D para ajudar os alunos a desenvolverem as suas habilidades clínicas como, por exemplo, sutura, punção venosa e anestesia, onde um profundo conhecimento de estruturas anatômicas é essencial para alcançar a competência nessas habilidades. Tem-se argumentado que a capacidade espacial dos alunos pode ajudar esse entendimento anatômico, e que essa capacidade pode ser desenvolvida usando modelos 3D (BOYD; CLARKSON; MATHER, 2015).

A dissecação de cadáveres, geralmente, é considerada padrão para aprender as relações anatômicas e a manipulação dos tecidos. No entanto com a disponibilidade dos cadáveres em declínio, bem como a moral e questões éticas em torno do seu uso, muitas instituições estão produzindo métodos alternativos para as atividades de ensino da anatomia (PREECE et al., 2013). 
Segundo pesquisas, a disciplina de anatomia junto com a disciplina de técnica cirúrgica é uma das disciplinas que usam um maior número de animais, principalmente devido às dissecações e preparo de peças utilizadas nas aulas práticas (GEBARA, 2015).

Sabe-se que a técnica de dissecação deve ser realizada em animais que morreram de formas naturais ou que foram eutanasiados por motivos de doença, ou seja, devem ser utilizados "cadáveres de fonte ética", que na maioria das vezes são cadáveres doados pelos tutores dos animais, com doação formalizada pela faculdade (GEBARA, 2015). Como nos dias de hoje os animais conquistaram espaços como "membros da família", estas doações de cadáveres tendem a ficar cada vez mais escassas.

Outro inconveniente do uso de peças anatômicas e cadáveres é a exposição do usuário (professores e alunos) aos produtos químicos, como a formalina, normalmente utilizados na fixação das peças (DRAKE; PAWLINA, 2014). Essas peças também podem apresentar um desgaste devido à ação das substâncias utilizadas para sua conservação, causando alterações de importantes características, como forma e cor. (PREECE et al., 2013).

O uso de animais nas atividades de ensino vem provocando discussões de cunho ético, levando muitas vezes professores e pesquisadores a refletirem sobre essa prática, buscando estabelecer limites para essa utilização. No Brasil após várias discussões a respeito desse assunto foi oficializada a Lei Arouca em 2008 (BRASIL,2008), que orienta sobre a utilização de animais no ensino e na pesquisa no território nacional (FEIJÓ; BRAGA; PITREZ, 2010).

Ainda se tratando de questões éticas, a objeção de consciência pode estimular à introdução de atividades alternativas, sendo os objetores estudantes preocupados com o uso de animais e com a qualidade da sua educação e estando preparados para questionar normas estabelecidas. A objeção de consciência representa uma recusa à metodologia científica oficial, permitindo que os estudantes respeitem suas convicções, sem vivenciar a violação de sua integridade moral, espiritual, política, cultural, dentre outras. Assim, o estudante pode utilizar um fundamento jurídico que lhe dá o direito de não ser vítima de um ensino que fere os seus princípios morais (SEIXAS et al., 2010).

Considerando essa variedade de limitações como pedagógicas, éticas e econômicas, torna-e necessário pesquisas que busquem modelos anatômicos que 
apresentem características físicas muito próximas a do animal verdadeiro, e que possam ser usados seguramente nas atividades de ensino, sem prejuízo ao aprendizado do aluno (LI et al., 2017).

\subsection{DIGITALIZAÇÃO E IMPRESSÃO TRIDIMENSIONAL}

Para a produção de um biomodelo é necessário um modelo virtual o qual pode ser obtido a partir de um modelo físico. Esse processo é conhecido como engenharia reversa e pode ser realizado via digitalização tridimensional (SILVA, 2011).

A digitalização tridimensional é utilizada para capturar dados de objetos em 3D e, auxiliada por softwares, permite obter com grande precisão curvas, detalhes de superfícies e textura. A partir da digitalização 3D é possível o desenvolvimento de produtos personalizados. Para estas aplicações, normalmente, são utilizados sistemas de alta tecnologia como o Scanner 3D. Embora esses sistemas venham se popularizando para o mercado nacional eles ainda requerem elevados investimentos (SILVA, 2011).

O sistema de digitalização a laser tende a apresentar um custo mais elevado devido aos componentes físicos do aparelho como unidades óticas e motores de posicionamento, porém esses mesmos fatores o torna bastante preciso (SILVA, 2011).

\subsubsection{Digitalização a Laser por Triangulação}

Os digitadores a laser baseados na triangulação já estão bem difundidos no mercado atual. A maioria dos aparelhos utiliza uma câmera para obter a linha de intersecção do laser com o objeto. Após ser finalizada a varredura da área superficial de interesse, obtém-se o mapeamento ponto a ponto da superfície do objeto. Como resultados, podem ser exportados arquivos com milhares de pontos descritos em coordenadas (X, Y, Z). Este conjunto de pontos é chamado "nuvens de pontos" e após manipulação computacional pode gerar superfícies tridimensionais (SILVA, 2011).

Atualmente encontram-se disponíveis no mercado scanners de mão (handheld scanner) como é o caso dos modelos da marca Creaform®. Estes são 
portáteis, dispensando o uso de tripés, braços mecânicos ou outros dispositivos de posicionamento. A operação é manual na qual o usuário varre o objeto como se estivesse operando uma pistola de pintura. Para tanto podem ser utilizadas etiquetas reflexivas como alvos (targets) na superfície a ser digitalizada. Com a identificação doa alvos, o sistema realiza um autoposicionamento, apresentando os resultados na tela de um computador em tempo real (SILVA, 2011).

\subsubsection{Modelamento computacional}

Os modelos de digitalização funcionam, portanto, por meio de uma varredura em intervalos regulares medindo a localização de pontos no espaço ( $X, Y$ e Z $)$. Com intervalos pequenos entre os pontos obtêm-se uma resolução regular da superfície do modelo original chamada nuvem de pontos. Uma nuvem de pontos 3D adquirida através de digitalização tridimensional, normalmente necessita de algum tipo de pósprocessamento, como suavização, aplicação de filtros, preenchimento, montagem de partes entre outras. Estas operações são realizadas por softwares especializados que permitem realizar uma série de alterações como suavizar a superfície, criar furos, alterar cantos vivos entre outras possibilidades. Esses arquivos editados podem ser salvos com a extensão STL (Stereolithography ou Standard Triangulation Language) formato padrão utilizado pelas impressoras tridimensionais (SILVA, 2011).

Para as operações de processamento da nuvem de pontos 3D um dos softwares mais conhecidos no mercado é o Geomagic ${ }^{\circledR}$, capaz de automaticamente transformar os dados digitalizados (nuvem de pontos) em malhas de polígonos (aplicada na edição de imagem). O software possui ferramentas para suavização, filtros de pontos, modelagem avançada e módulos para realizar análises e comparações entre os dados tridimensionais (SILVA, 2011).

\subsubsection{Impressão tridimensional (3D)-Sistema FDM (Fusion Deposition Modeling)}

O Sistema FDM ou modelagem por deposição de material fundido utilizam um filamento plástico (ABS, policarbonato, poliéster, etc) que é desenrolado de uma bobina, e expelido por um bocal de extrusão acoplado a um mecanismo que o move 
nos sentidos horizontal $(\mathrm{x})$ e vertical $(\mathrm{y})$. Esse bocal é aquecido para derreter $\mathrm{o}$ filamento plástico, que é depositado camada a camada, formando o objeto. $\mathrm{O}$ sistema FDM é razoavelmente rápido para pequenas peças. Entretanto, pode ser muito lento para peças mais maciças (SAURA, 2003) (Figura 1).

As impressoras 3D FDM apresentam algumas características que envolvem a confecção de diferentes tipos de produtos resultantes do processo de impressão. Elas são capazes de imprimir: peças de qualquer forma, com geometrias complexas, dispositivos funcionais obtidos em uma única impressão (MOREIRA, 2016)

Além da infinidade e variedade de produtos que é possível de se obter com o uso desse tipo de impressão é possível poupar muito material por não existirem desperdícios significativos, a possibilidade de redução de material em zonas que não conferem grande rigidez estrutural, ou mesmo a elaboração de padrões de impressão que reduzem a quantidade de material da peça, mas conferem elevada rigidez (MOREIRA, 2016)

Figura 1: Princípio de funcionamento de uma impressora 3D FDM

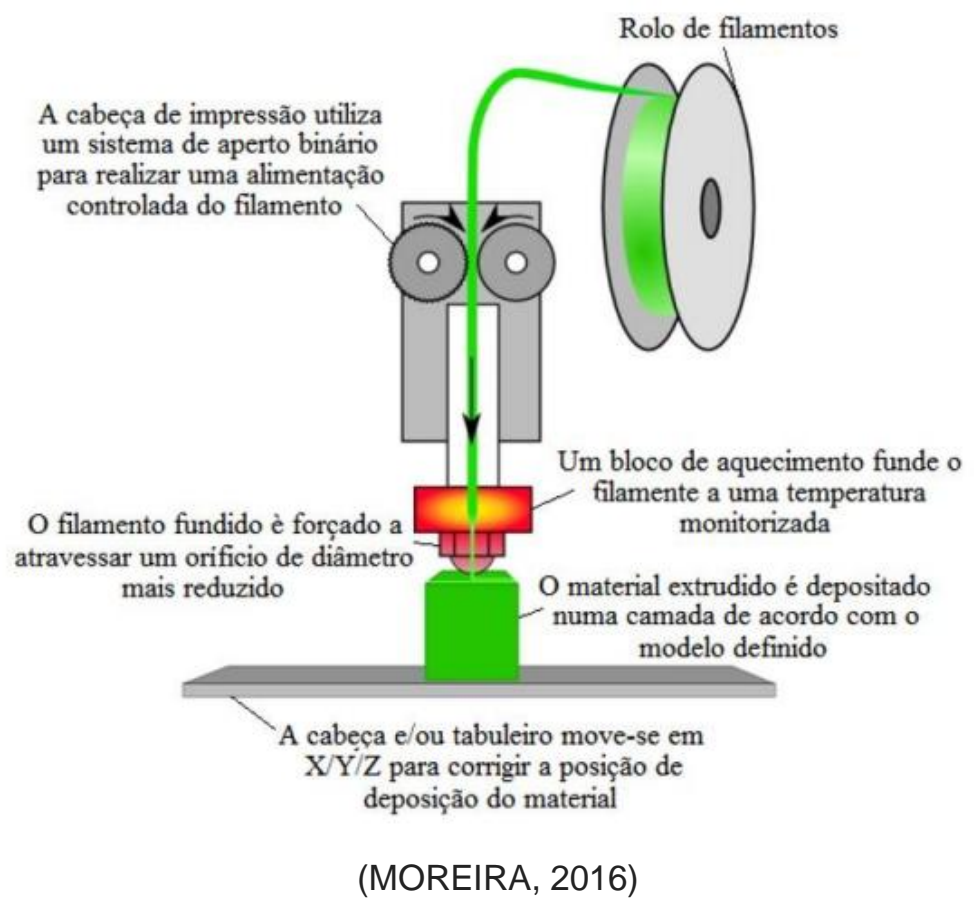




\section{MATERIAIS E MÉTODOS}

A pesquisa foi autorizada pelo Comitê de Ética da Faculdade de Medicina Veterinária e Zootecnia da Universidade de São Paulo, São Paulo, Brasil (protocolo 4923110716).

\subsection{PEÇAS DO ESQUELETO EQUINO}

As peças ósseas de um equino adulto usadas no estudo são da coleção de do Laboratório de Anatomia Faculdade de Medicina Veterinária e Zootecnia da Universidade de São Paulo. Foram usados ossos do membro torácico esquerdo: a escápula, úmero, rádio e ulna, ossos metacarpianos, osso carpo acessório, carpo ulnar, carpo intermédio, carpo radial, segundo cárpico, terceiro cárpico, quarto cárpico, sesamoides proximais, falange proximal, falange média, falange distal e sesamoide distal foram selecionados para digitalização e criação dos modelos tridimensionais.

Foi escolhida a espécie equina, pois essa é utilizada como padrão para estudo da osteologia na disciplina de anatomia do curso de Medicina Veterinária da Universidade de São Paulo.

\subsection{DIGITALIZAÇÃO ÓSSEA E MODELAGEM}

As peças do esqueleto foram utilizadas usando o scanner GO!SCAN 3D da marca Creaform $\AA$. A varredura foi realizada no laboratório de anatomia e o scanner foi calibrado antes da aquisição para verificar o tamanho absoluto dos objetos digitalizados.

O scanner é portátil e seu peso é de aproximadamente $1,0 \mathrm{~kg}$ e para a operação é necessário um notebook. A triangulação com o laser emitido é realizada com duas câmeras dispostas nas extremidades do aparelho, para a captura do objeto. A operação é manual, mas o sistema realiza um autoposicionamento das nuvens de pontos. Para a montagem automática de pontos é indicado o uso de etiquetas reflexivas no objeto. Esses alvos são iluminados pelos LEDs (emissores de luz) dispostos em volta das câmeras do aparelho para a aquisição de pontos (Figura 2). Através do registro desses alvos o sistema calcula a posição do scanner e 
permite que o mesmo possa ser movido em relação ao objeto digitalizado, permitindo que a superfície possa ser varrida sem a necessidade de gerar vários arquivos de diferentes vistas da peça.

A distância do scanner ao objeto (aproximadamente $30 \mathrm{~cm}$ ) deve ser controlada utilizando a barra de escala existente na tela do software de operação do scanner, o VXelements. Foram realizadas cinco varreduras de cada peça a qual demandou aproximadamente 10 minutos cada. Como o próprio sistema faz o registro automático de pontos, foi utilizado apenas o próprio software para a geração da malha de polígonos.

Figura 2: Imagem do Scanner manual

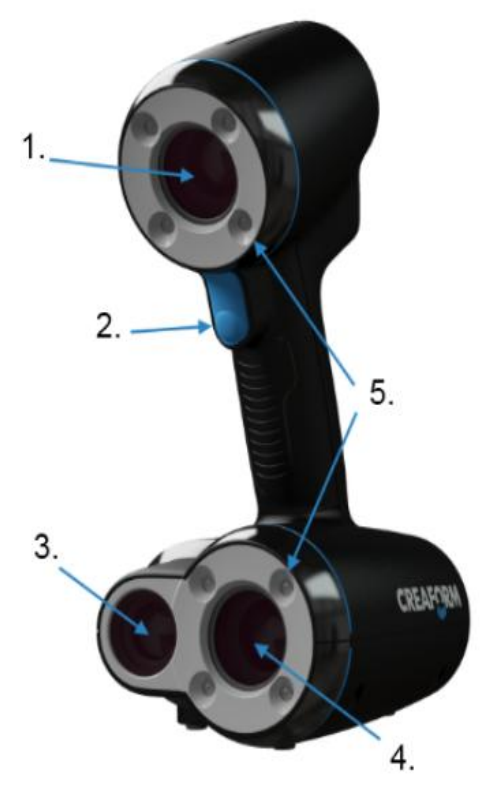

Legenda: 1 câmera superior, 2 gatilho, 3 projetor padrão de luz, 4 câmera inferior, 5 LEDs (https://www.goscan3d.com/pt/vxmodel-modulo-do-software-digitalizador-para-cad)

A nuvem de pontos 3D foi então transferida para o software de edição Geomagic $\AA$ para passar por um processo de edição que permite 0 aprimoramento das imagens, sendo este também um software de interface com capacidade de conversão do arquivo 3D em camadas de impressão (Figura 3). 
Figura 3: Imagens digitalizadas e editadas dos ossos do membro torácico do equino. Software Geomagic ${ }^{\circledR}$

A

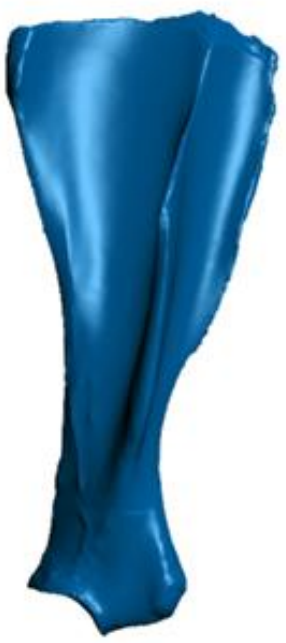

D

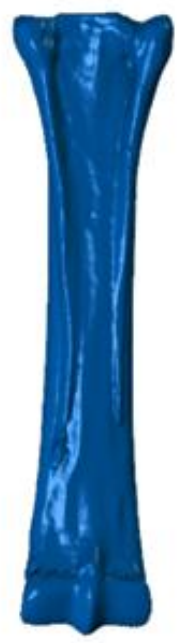

G

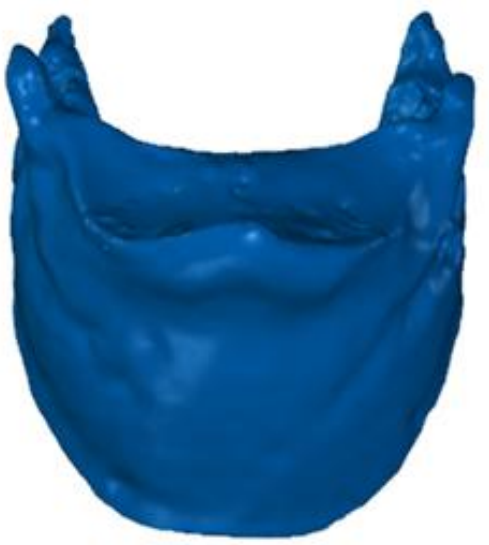

B

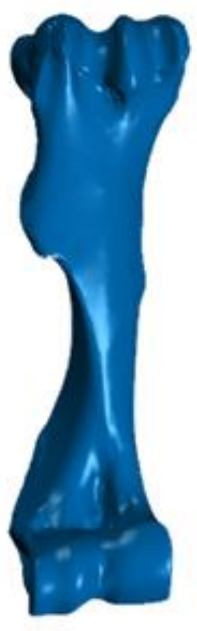

C

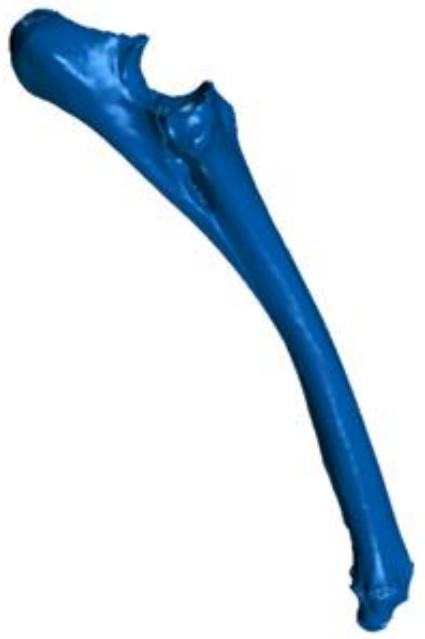

E

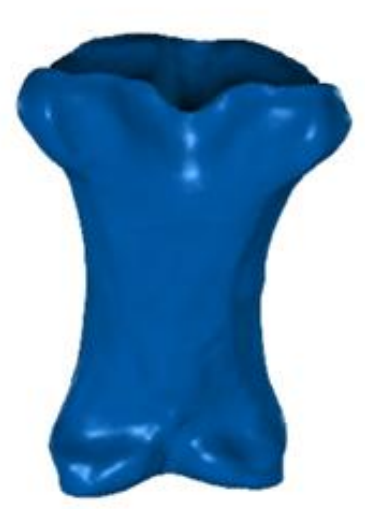

$\mathrm{H}$

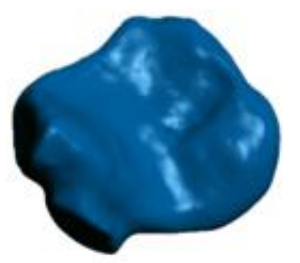

$\mathrm{F}$
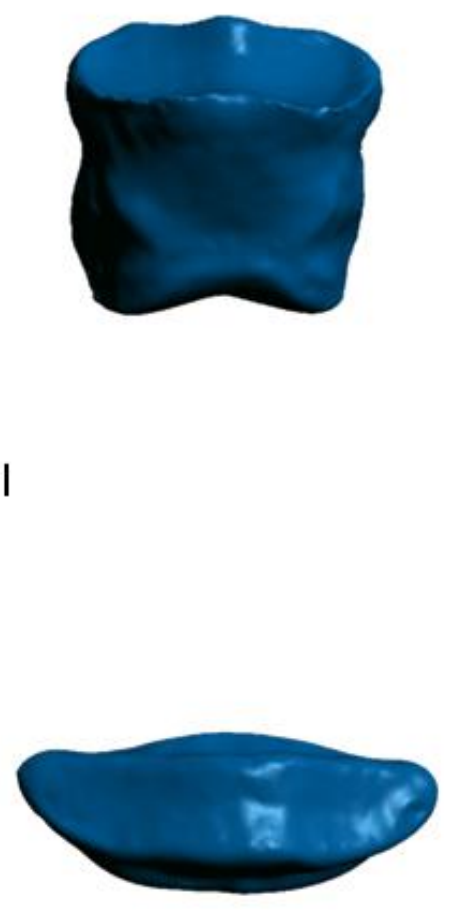

(REIS, 2018)

Legenda: A- escápula, B-úmero, C- radio e ulna, D- metacarpianos, E- falange proximal, F- falange média, G- falange distal, $\mathrm{H}$ - osso carpo acessório, I- sesamoide distal. 


\subsection{A IMPRESSÃO TRIDIMENSIONAL}

Os modelos digitais foram processados para arquivos com extensão STL através software de edição Geomagic ${ }^{\circledR}$ para poder ser realizado o processo de impressão.

A impressão dos arquivos digitais para a produção das peças (biomodelos) foi realizada através da impressora 3D (Stratasys Mojo Printerß). A impressora tem capacidade de impressão utilizando um material termoplástico em forma de filamento (ABS- Acrilonitrila butadieno estireno) e cujo método de trabalho é a deposição deste material juntamente com um material de suporte que é removido posteriormente.

O modelo da impressora 3D utilizada apresenta uma placa de base para impressão com dimensões $12,7 \mathrm{~cm} \times 12,7 \mathrm{~cm}$, portanto peças com grandes dimensões foram impressas em mais de uma etapa.

O tempo de impressão de cada peça leva algumas horas que podem variar de dependendo do seu tamanho e se apresenta muitos detalhes.

As peças impressas são submetidas a um processo de limpeza em uma lavadora WaveWash 55 - Stratasys ${ }^{\circledR}$ a fim de remover a resina de suporte, obtendo dessa forma apenas a peça produzida. Nesse processo de limpeza, que dura aproximadamente 8 horas, a lavadora necessita de um agente detergente de limpeza especial (Ecoworks Tablets Cleaning Agent $\AA$ ) que remove apenas a resina de suporte.

\subsection{ANÁLISES COMPARATIVAS DOS OSSOS E BIOMODELOS}

Foram escolhidos alguns detalhes anatômicos presentes em cada osso escolhido para o estudo. As dimensões dessas estruturas nos osso e nos modelos impressos tridimensionalmente foram medidas por um único observador usando um paquímetro digital. As características anatômicas das peças ósseas e dos modelos 3D impressos também foram analisadas visualmente e comparadas com o livro texto de anatomia veterinária de mamíferos domésticos (GETTY, 1986; POSPEKO, 1990, KONIG \& LIEBICH, 2002, DONE, 2012).

Foi realizada a comparação dos pesos dos ossos e dos biomodelos com uso de balança digital. 


\section{RESULTADOS}

Os resultados foram divididos em:

\subsection{TEMPOS DE IMPRESSÃO E CONSUMO DE MATERIAL}

Devido a razões que envolvem a capacidade de impressão da máquina usada no projeto, as peças que apresentavam maiores dimensões, mesmo sendo impressas em duas etapas tiveram seu tamanho reduzido automaticamente pela impressora para se adequar aos padrões de impressão, sendo assim temos:

- Escápula: modelo impresso com $75 \%$ do tamanho do osso (modelo foi impresso em duas partes que depois foram unidas com cola instantânea);

- Úmero: modelo impresso com $80 \%$ do tamanho do osso (modelo foi impresso em duas partes que depois foram unidas com cola instantânea);

- Rádio e Ulna: modelo impresso com $70 \%$ do tamanho do osso (modelo foi impresso em duas partes que depois foram unidas com cola instantânea);

- Metacarpianos (II III e IV): modelo impresso em escala real (modelo foi impresso em duas partes que depois foram unidas com cola instantânea);

- Ossos do Carpo: modelos impressos em escala real;

- Falanges: modelos impressos em escala real;

- Sesamóides: modelos impressos em escala real.

O tempo de impressão variou com o tamanho e complexidade da peça, assim como o consumo de material para sua impressão. O consumo de material de suporte também dependeu do tamanho da peça e como o modelo digital foi posicionado na bandeja de impressão antes do processo se iniciar (Tabela 1) 
Tabela 1: Tempo de impressão dos modelos 3D, quantidade de material usado na impressão da peça e quantidade de material de suporte utilizado em cada impressão.

\begin{tabular}{cccc}
\hline Ossos & $\begin{array}{c}\text { Tempo de Impressão } \\
\text { (horas) }\end{array}$ & $\begin{array}{c}\text { Material da Peça- } \\
\text { ABS }\left(\mathbf{c m}^{3}\right)\end{array}$ & $\begin{array}{c}\text { Material de Suporte } \\
\left(\mathbf{c m}^{3}\right)\end{array}$ \\
\hline Escápula & 10 horas e 31 minutos & 52,8 & 48,3 \\
Úmero & 14 horas e 16 minutos & 87,2 & 43,0 \\
Rádio e Ulna & 10 horas & 51,8 & 28,3 \\
Metacarpo & 9 horas e 42 minutos & 62,3 & 28,5 \\
Carpo Acessório & 1 hora e 51 minutos & 8,7 & 4,5 \\
Carpo Intermédio & 1 hora e 43 minutos & 8,2 & 3,6 \\
Carpo Radial & 2 horas e 23 minutos & 10,4 & 5,6 \\
Carpo Ulnar & 1 hora e 10 minutos & 5,2 & 2,4 \\
IV Cárpico & 1 hora e 6 minutos & 4,9 & 1,9 \\
II Cárpico & 32 minutos & 2,7 & 0,6 \\
III Cárpico & 1 hora e 56 minutos & 9,6 & 3,4 \\
Falange Proximal & 3 horas e 51 minutos & 31,8 & 7,3 \\
Falange Média & 3 horas e 5 minutos & 18,3 & 7,5 \\
Falange Distal & 5 horas e 46 minutos & 26,5 & 16,5 \\
Sesamoide proximal 1 & 1 hora e 5 minutos & 4,7 & 2,1 \\
\hline Sesamoide proximal 2 & 53 minutos & 4,3 & 1,5 \\
Sesamoide Distal & 1 hora e 7 minutos & 3,8 & 2,6 \\
\hline (REIS, 2018) & & \\
\hline
\end{tabular}

(REIS, 2018)

Legenda: ABS- Acrilonitrila Butadieno Estireno

\subsubsection{Comparação entre o peso dos ossos e os modelos impressos}

O material termoplástico usado na impressão permite a produção de modelos com pesos leves, porém apresentam certa rigidez e resistência (Tabela 2). 
Tabela 2: Valores comparativos entre os pesos dos ossos e dos modelos impressos (em gramas).

\begin{tabular}{ccc}
\hline Ossos & $\begin{array}{c}\text { Peso dos ossos } \\
\text { (em gramas) }\end{array}$ & $\begin{array}{c}\text { Peso dos modelos impressos } \\
\text { (em gramas) }\end{array}$ \\
\hline Escápula & 588 & 77 \\
Úmero & 763 & 148 \\
Rádio e Ulna & 724 & 99 \\
Metacarpo & 319 & 89 \\
Falange proximal & 106 & 30 \\
Falange média & 56 & 18 \\
Falange distal & 55 & 24 \\
Ossos do carpo (pesados & 115 & 44 \\
juntos) & & 7 \\
\hline Ossos sesamoide & 22 & \\
proximal 1 e 2 (pesados & & 2 \\
\hline juntos) & 5 & \\
\hline Osso sesamoide distal & & \\
\hline
\end{tabular}

(REIS, 2018)

\subsection{CUSTOS APROXIMADOS DE CADA PEÇA PRODUZIDA}

$\mathrm{Na}$ tabela a seguir estão relacionados os custos aproximados das peças produzidas, pois foram consideradas somente as despesas com o material de impressão que constitui a peça e de suporte (Tabela 3).

Tabela 3: Custo com material para impressão dos biomodelos

\begin{tabular}{|cc}
\hline Modelo Impresso & $\begin{array}{c}\text { Custo com material para Impressão } \\
\text { (Valores expressos em R\$) }\end{array}$ \\
\hline Escápula & 205,00 \\
Úmero & 264,00 \\
Rádio e Ulna & 162,50 \\
Metacarpo & 184,20 \\
Carpo acessório & 26,70 \\
Carpo intermédio & 24,00 \\
Carpo radial & 32,50 \\
Carpo ulnar & 15,40 \\
IV Cárpico & 13,80 \\
II Cárpico & 6,70 \\
III Cárpico & 26,40 \\
\hline
\end{tabular}


(continuação)

\begin{tabular}{cc}
\hline Modelo Impresso & $\begin{array}{c}\text { Custo com material para Impressão } \\
\text { (Valores expressos em R } \$ \text { ) }\end{array}$ \\
\hline Falange proximal & 79,30 \\
Falange média & 52,30 \\
Falange distal & 87,20 \\
Sesamoide proximal 1 & 13,80 \\
Sesamoide proximal 2 & 11,80 \\
Sesamoide distal & 13,00 \\
\hline (REIS, 2018) & \\
Legenda: Cálculo dos custos considerando a cotação com valores expressos em Reais $(\mathrm{R} \$)$, no \\
período de outubro de 2016, correspondente ao material que compõe a peça e ao material de \\
suporte, cada um com preço de $R \$ 2.659,00$ a embalagem com a quantidade de $1.311 \mathrm{~cm}^{3}$ de \\
material (Cotação fornecida pela empresa Anacom).
\end{tabular}

\subsection{COMPARAÇÕES DOS DETALHES ANATÔMICOS}

Foram realizadas medidas de alguns detalhes anatômicos presentes nos osso e nos modelos impressos tridimensionalmente. Essa medição foi realizada por um único observador, por três vezes e usando um paquímetro digital.

\subsubsection{Escápula}

As dimensões e detalhes anatômicos medidos na escápula são apresentados na tabela abaixo. Considerar que as dimensões das estruturas anatômicas dos modelos impressos apresentam um tamanho consideravelmente menor, pois a peça foi produzida com $75 \%$ do tamanho do osso, por isso foi apresentado um valor corrigido (Tabela 4).

Tabela 4: Medidas das estruturas anatômicas na escápula e no biomodelo impresso.

\begin{tabular}{cccc}
\hline $\begin{array}{c}\text { Dimensões/Estruturas } \\
\text { anatômicas }\end{array}$ & Ossos $(\mathrm{mm})$ & Modelo Impresso $(\mathrm{mm})$ & Valor corrigido \\
\hline $\begin{array}{c}\text { Largura da escápula } \\
\text { (medida entre o ângulo } \\
\text { cranial e ângulo caudal) } \\
\text { Colo da escápula }\end{array}$ & 177,3 & 120,4 & 160,5 \\
$\begin{array}{c}\text { Cavidade glenoide- } \\
\text { medida craniocaudal }\end{array}$ & 67,4 & 46,2 & 61,6 \\
$\begin{array}{c}\text { Cavidade glenoide- } \\
\text { medida lateromedial }\end{array}$ & 52,7 & 42,3 & 56,4 \\
\end{tabular}


(continuação)

\begin{tabular}{cccc}
\hline $\begin{array}{c}\text { Dimensões/Estruturas } \\
\text { anatômicas }\end{array}$ & Ossos $(\mathrm{mm})$ & Modelo Impresso $(\mathrm{mm})$ & Valor corrigido \\
\hline $\begin{array}{c}\text { Tuberosidade da } \\
\text { espinha da escápula } \\
\text { (espessura) }\end{array}$ & 8,3 & 5,1 & 6,8 \\
$\begin{array}{c}\text { Tubérculo } \\
\text { supraglenoidal -medida } \\
\text { lateromedial }\end{array}$ & 28,6 & 19,9 & 26,5 \\
$\begin{array}{c}\text { Comprimento da } \\
\text { escápula (da margem } \\
\text { cranial da cavidade } \\
\text { glenoide até a borda } \\
\text { dorsal) }\end{array}$ & 410,3 & 278,9 & 371,9 \\
\hline
\end{tabular}

(REIS, 2018)

\subsection{2 Úmero}

Os detalhes anatômicos medidos no úmero são apresentados na tabela abaixo. Considerar que as dimensões das estruturas anatômicas dos modelos impressos apresentam um tamanho consideravelmente menor, pois a peça foi produzida com $80 \%$ do tamanho do osso, por isso foi apresentado um valor corrigido (Tabela 5).

Tabela 5: Medidas das estruturas anatômicas no úmero e no biomodelo impresso

\begin{tabular}{|c|c|c|c|}
\hline $\begin{array}{c}\text { Dimensões/Estruturas } \\
\text { anatômicas }\end{array}$ & Ossos (mm) & Modelo Impresso (mm) & Valor corrigido \\
\hline $\begin{array}{c}\text { Tróclea do úmero } \\
\text { (medida lateromedial) }\end{array}$ & 74,1 & 58,5 & 73,1 \\
\hline $\begin{array}{c}\text { Tuberosidade } \\
\text { deltoide (espessura) }\end{array}$ & 12,2 & 9,4 & 11,7 \\
\hline $\begin{array}{l}\text { Tubérculo Intermédio } \\
\text { (espessura } \\
\text { lateromedial) }\end{array}$ & 21,3 & 16,7 & 20,9 \\
\hline Tubérculo maior & 21,4 & 16,8 & 21,0 \\
\hline Tubérculo menor & 16,7 & 11,7 & 14,6 \\
\hline $\begin{array}{l}\text { Sulco intertubercular } \\
\text { (entre os tubérculos } \\
\text { intermédio e maior) }\end{array}$ & 22,8 & 17,9 & 22,4 \\
\hline $\begin{array}{l}\text { Sulco intertubercular } \\
\text { (entre os tubérculos } \\
\text { intermédio e menor) }\end{array}$ & 18,3 & 15,0 & 18,7 \\
\hline $\begin{array}{l}\text { Cabeça do úmero } \\
\text { (medida lateromedial) }\end{array}$ & 67,4 & 50,4 & 63,0 \\
\hline
\end{tabular}

(REIS, 2018) 


\subsubsection{Rádio e Ulna}

Os detalhes anatômicos medidos no rádio e ulna são apresentados na tabela abaixo. Considerar que as dimensões das estruturas anatômicas dos modelos impressos apresentam um tamanho consideravelmente menor, pois a peça foi produzida com $70 \%$ do tamanho do osso, por isso foi apresentado um valor corrigido (Tabela 6).

Tabela 6: Medidas das estruturas anatômicas no rádio e na ulna e no biomodelo impresso

\begin{tabular}{|c|c|c|c|}
\hline $\begin{array}{c}\text { Dimensões/Estruturas } \\
\text { anatômicas }\end{array}$ & Ossos (mm) & Modelo Impresso (mm) & Valor corrigido \\
\hline $\begin{array}{c}\text { Espessura entre a } \\
\text { tuberosidade medial e } \\
\text { tubérculo lateral }\end{array}$ & 81,1 & 56,0 & 80,0 \\
\hline $\begin{array}{l}\text { Espessura do } \\
\text { processo ancôneo da } \\
\text { ulna (medida } \\
\text { lateromedial) }\end{array}$ & 15,9 & 11,1 & 15,7 \\
\hline $\begin{array}{c}\text { Espessura da } \\
\text { tuberosidade do } \\
\text { olecrano da ulna } \\
\text { (medida lateromedial) }\end{array}$ & 37,9 & 25,4 & 36,3 \\
\hline $\begin{array}{c}\text { Processo estiloide } \\
\text { medial (medida } \\
\text { lateromedial) }\end{array}$ & 27,0 & 18,8 & 26,9 \\
\hline
\end{tabular}

(REIS, 2018)

\subsubsection{Ossos metacarpianos (II, III e IV)}

As dimensões e detalhes anatômicos medidos nos osso metacarpianos (II,III e IV) são apresentados na tabela abaixo. O modelo foi impresso em escala real (Tabela 7).

Tabela 7: Medidas das estruturas anatômicas nos ossos metacarpianos (II, II e IV) e no biomodelo impresso.

\begin{tabular}{ccc}
\hline $\begin{array}{c}\text { Dimensões/Estruturas } \\
\text { anatômicas }\end{array}$ & Ossos (mm) & Modelo Impresso (mm) \\
\hline $\begin{array}{c}\text { Espessura da tróclea do III } \\
\text { metacarpiano (medida } \\
\text { leteromedial) }\end{array}$ & 50,1 & 50,5 \\
$\begin{array}{c}\text { Crista da tróclea do III } \\
\text { metacarpiano }\end{array}$ & 13,5 & 13,7 \\
$\begin{array}{c}\text { Espessura do II } \\
\text { metacarpiano (medida } \\
\text { craniocaudal) }\end{array}$ & 21,9 & 23,2 \\
\hline
\end{tabular}


(continuação)

\begin{tabular}{ccc}
\hline $\begin{array}{c}\text { Dimensões/Estruturas } \\
\text { anatômicas }\end{array}$ & Ossos (mm) & Modelo Impresso (mm) \\
\hline $\begin{array}{c}\text { Espessura do IV } \\
\text { metacarpiano (medida } \\
\text { craniocaudal) }\end{array}$ & 20,3 & 20,4 \\
$\begin{array}{c}\text { Espessura da extremidade } \\
\text { distal (botão) do II } \\
\text { metacarpiano (medida } \\
\quad \text { lateromedial) }\end{array}$ & 5,5 & 5,8 \\
$\begin{array}{c}\text { Comprimento do III } \\
\text { metacarpiano (da } \\
\text { superfície articular até a } \\
\text { crista da troclea) }\end{array}$ & 248,6 & 248,9 \\
\hline REIS, 2018) & \\
\hline
\end{tabular}

\subsubsection{Falanges (proximal, média e distal)}

As dimensões e detalhes anatômicos medidos nas falanges proximal, falange média e falange distal são apresentados nas tabelas abaixo. Os modelos foram impressos em escala real (Tabelas 8,9 e 10).

Tabela 8: Medidas das estruturas anatômicas na falange proximal e no biomodelo impresso

\begin{tabular}{|c|c|c|}
\hline $\begin{array}{c}\text { Dimensões/Estruturas } \\
\text { anatômicas }\end{array}$ & Ossos (mm) & Modelo Impresso (mm) \\
\hline $\begin{array}{c}\text { Comprimento da falange } \\
\text { proximal }\end{array}$ & 84,2 & 84,6 \\
\hline $\begin{array}{c}\text { Espessura da superfície } \\
\text { articular proximal (entre as } \\
\text { eminências) (medida } \\
\text { lateromedial) }\end{array}$ & 56,0 & 56,5 \\
\hline $\begin{array}{c}\text { Espessura da superfície } \\
\text { articular distal (entre as } \\
\text { eminências) (medida } \\
\text { lateromedial) }\end{array}$ & 47,7 & 47,9 \\
\hline \multicolumn{3}{|l|}{ (REIS, 2018) } \\
\hline $\begin{array}{c}\text { Dimensões/Estruturas } \\
\text { anatômicas }\end{array}$ & Ossos (mm) & Modelo Impresso (mm) \\
\hline $\begin{array}{l}\text { Comprimento da falange } \\
\text { média }\end{array}$ & 44,8 & 45,1 \\
\hline $\begin{array}{l}\text { Largura da superfície } \\
\text { articular proximal }\end{array}$ & 53,4 & 53,6 \\
\hline $\begin{array}{l}\text { Largura da superfície } \\
\text { articular caudal }\end{array}$ & 51,4 & 52,2 \\
\hline
\end{tabular}

(REIS, 2018) 
Tabela 10: Medidas das estruturas anatômicas na falange distal e no biomodelo impresso

\begin{tabular}{|c|c|c|}
\hline $\begin{array}{c}\text { Dimensões/Estruturas } \\
\text { anatômicas }\end{array}$ & Ossos (mm) & Modelo Impresso (mm) \\
\hline $\begin{array}{l}\text { Distância do processo } \\
\text { extensor até a margem solear }\end{array}$ & 58,3 & 59,8 \\
\hline $\begin{array}{l}\text { Distância entre os processos } \\
\text { palmares lateral e medial }\end{array}$ & 67,5 & 67,8 \\
\hline $\begin{array}{l}\text { Espessura do processo } \\
\text { palmar lateral }\end{array}$ & 5,0 & 5,3 \\
\hline $\begin{array}{l}\text { Espessura do processo } \\
\text { palmar medial }\end{array}$ & 4,5 & 4,7 \\
\hline
\end{tabular}

(REIS, 2018)

\subsubsection{Ossos do carpo e sesamoide distal}

Sendo ossos irregulares, o que dificulta uma mensuração precisa, os ossos e réplicas do carpo e sesamoide distal foram avaliados em dois eixos (eixo $x$ e eixo y) perpendiculares entre si. Os modelos foram impressos em escala real (Tabela 11)

Tabela 11: Medidas das estruturas anatômicas dos ossos do carpo e nos biomodelos impressos

\begin{tabular}{|c|c|c|}
\hline & Ossos (mm) & Modelo Impresso (mm) \\
\hline \multicolumn{3}{|l|}{ Carpo Radial } \\
\hline Eixo $x$ & 24,2 & 25,1 \\
\hline Eixo y & 38,1 & 39,0 \\
\hline \multicolumn{3}{|l|}{ Carpo Intermédio } \\
\hline Eixo $x$ & 33,9 & 34,0 \\
\hline Eixo y & 38,5 & 39,5 \\
\hline \multicolumn{3}{|l|}{ Carpo Ulnar } \\
\hline Eixo $x$ & 29,9 & 30,9 \\
\hline Eixo y & 30,4 & 31,2 \\
\hline \multicolumn{3}{|l|}{ Carpo Acessório } \\
\hline Eixo $x$ & 48,2 & 48,1 \\
\hline Eixo y & 37,8 & 38,8 \\
\hline \multicolumn{3}{|l|}{ II Cárpico } \\
\hline Eixo $x$ & 23,2 & 24,2 \\
\hline Eixo y & 20,5 & 20,6 \\
\hline \multicolumn{3}{|l|}{ III Cárpico } \\
\hline Eixo $x$ & 43,8 & 44,5 \\
\hline Eixo y & 33,7 & 34,7 \\
\hline
\end{tabular}


(continuação)

\begin{tabular}{rr|c|c}
\hline & Ossos $(\mathbf{m m})$ & Modelo Impresso $(\mathbf{m m})$ \\
\hline IV Cárpico & & 26,1 \\
Eixo x & 25,2 & 30,6 \\
Eixo y & 30,3 & \\
\hline Sesamoide distal & & 48,5 \\
Eixo x & 48,2 & 18,6 \\
Eixo y & 17,7 & \\
\hline
\end{tabular}

(REIS, 2018)

\subsubsection{Análise estatística das medidas}

Para validar a possibilidade de serem utilizados os modelos de ossos impressos, garantindo que não há prejuízo em relação aos ossos reais, do ponto de vista de escala e tamanho, foi calculado o valor-p entre todas as medições dos ossos reais e todas as medições dos modelos impressos. O valor-p obtido foi de 0,9126 indicando haver sólida evidência de compatibilidade entre as amostras, e descartando a hipótese de influência negativa significativa entre as medidas das peças trabalhadas.

\subsection{ANÁLISES DOS DETALHES ANATÔMICOS}

Os ossos e os modelos impressos foram analisados visualmente, sendo considerado o tamanho, o contorno ósseo e as principais características anatômicas de cada um, de acordo com livros de textos de anatomia veterinária de mamíferos domésticos (GETTY, 1986; POSPEKO, 1990, KONIG \& LIEBICH, 2002, DONE, 2012)

\subsubsection{Características anatômicas do modelo impresso 3D da escápula}

Ao realizar a análise visual da escápula e de sua cópia há uma diferença significativa em relação ao comprimento e a largura, pois devido às limitações da impressora a cópia foi produzida com $75 \%$ do tamanho original. Características anatômicas como a espinha da escápula, a tuberosidade da espinha da escápula, e 
cavidade glenoide apresentaram-se bem definidas no modelo impresso (Figura 4, 5 e 6).

O modelo da escapula foi produzida em duas partes, seguida da união dessas com cola instantânea.

Figura 4: Escápula esquina esquerda, vista lateral.

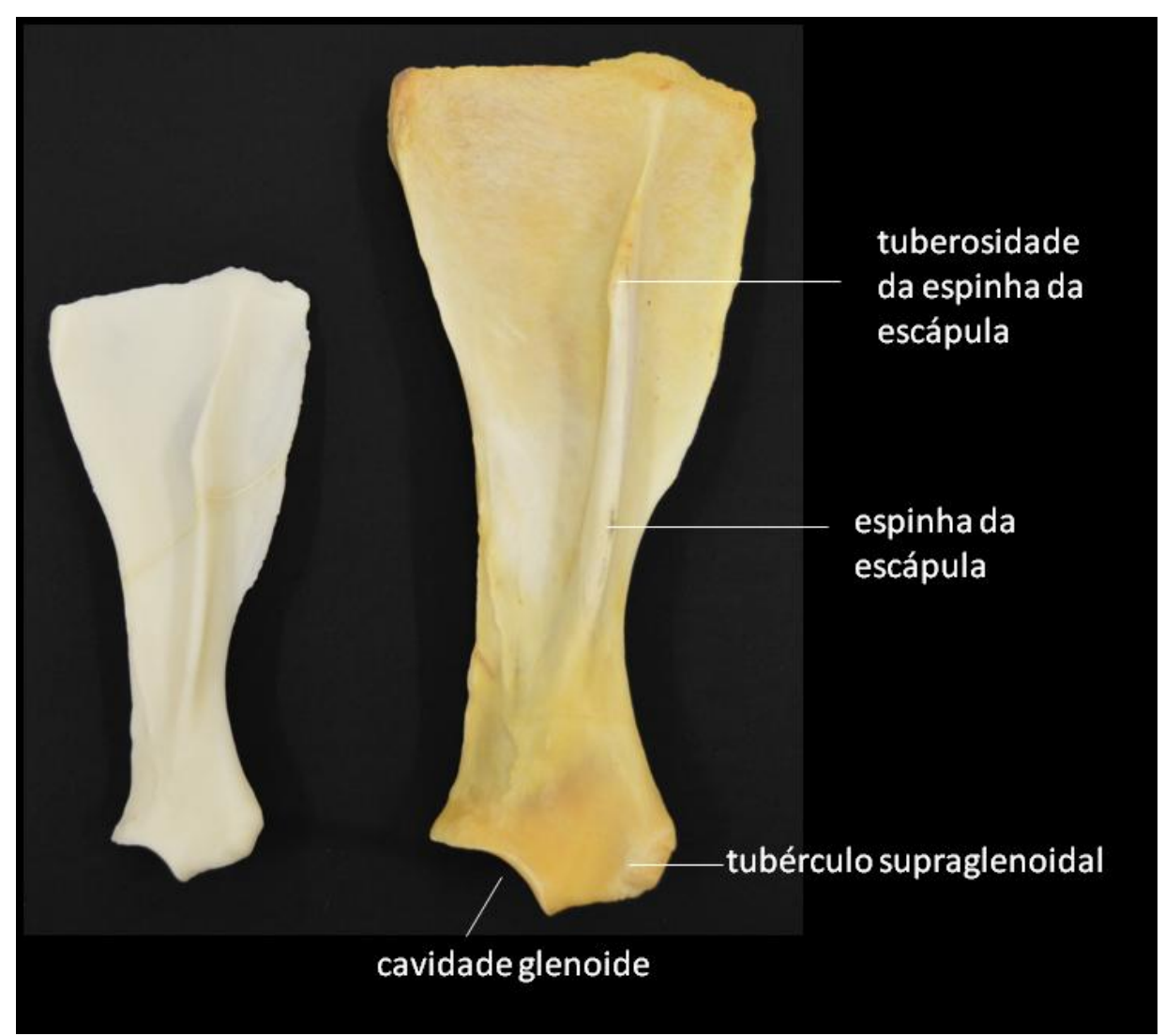

(REIS, 2018) 
Figura 5: Escápula esquina esquerda, vista medial.

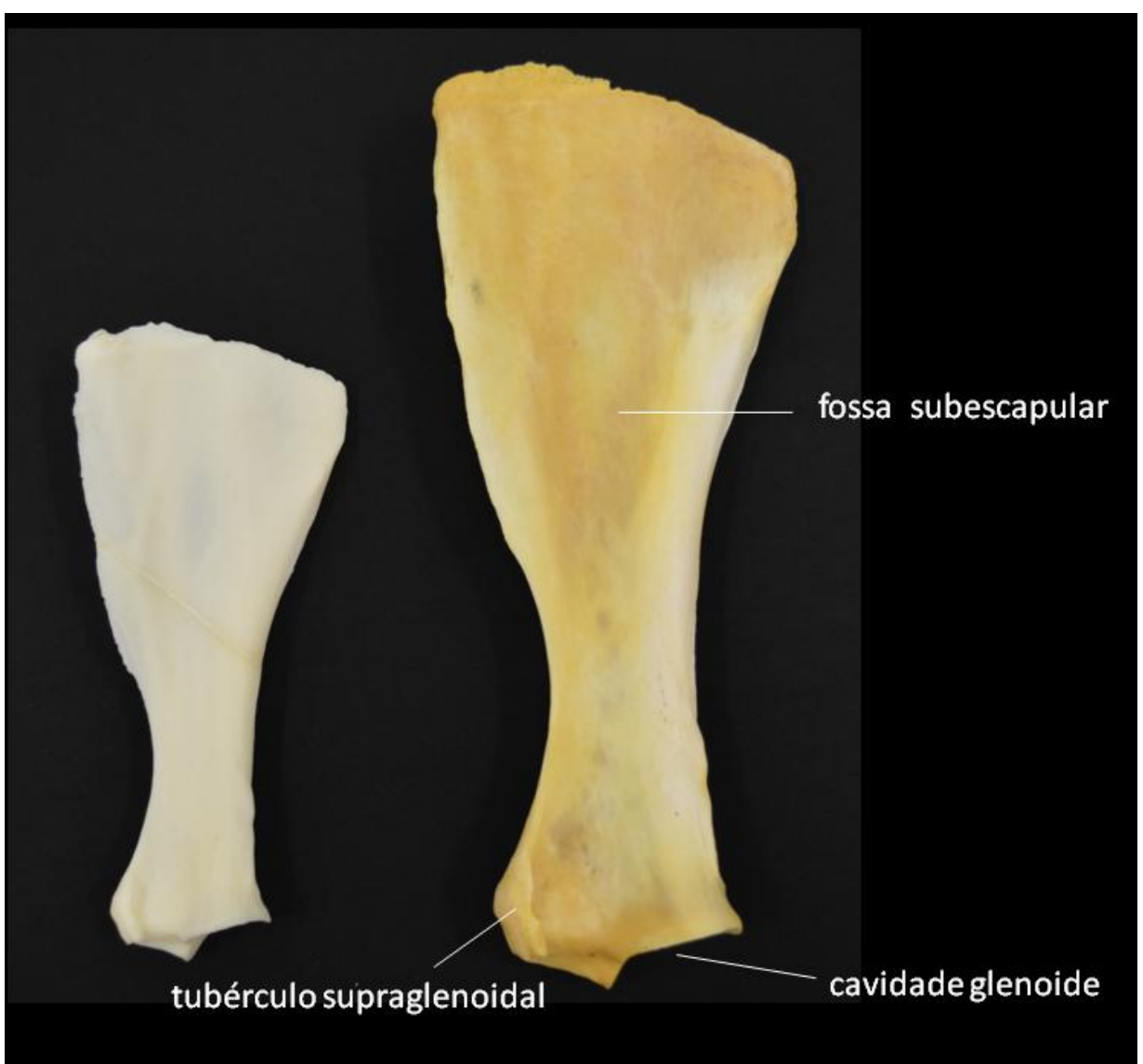

(REIS, 2018)

Figura 6: Escápula esquina esquerda, destaque para cavidade glenoide e tubérculo supraglenoidal

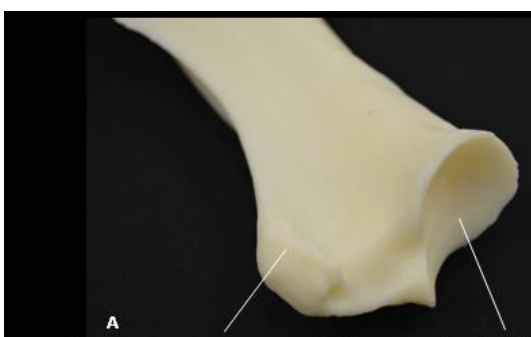

tubérculo supraglenoidal cavidadeglenoide

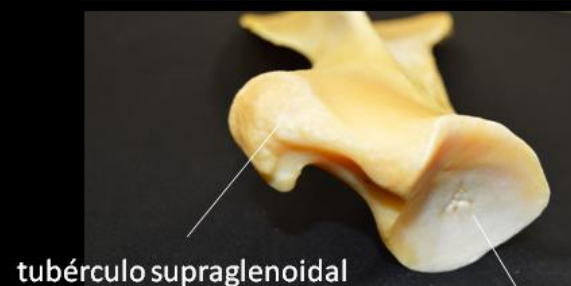

cavidadeglenoide
B tubérculo supraglenoidal
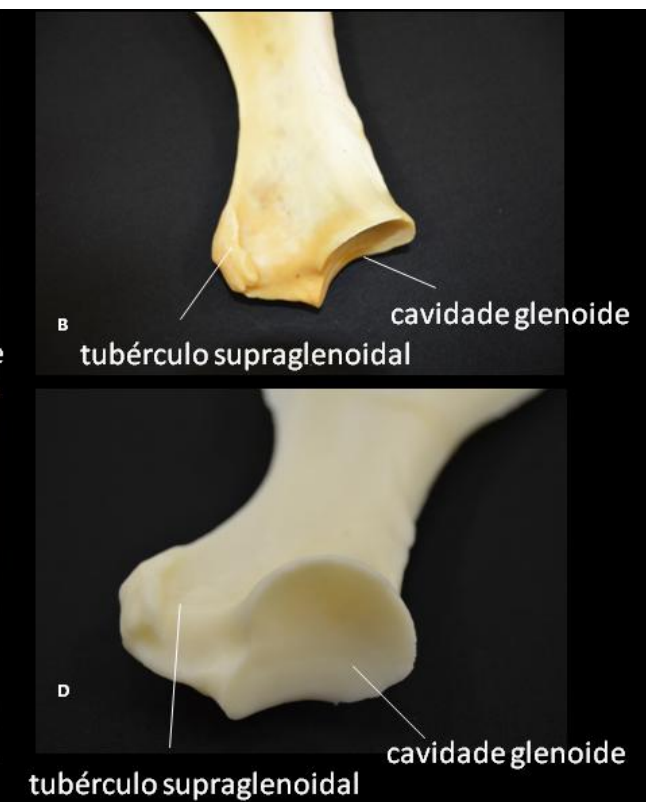

(REIS, 2018)

Legenda: A e B biomodelo da escápula, B e C escápula equina 


\subsubsection{Características anatômicas do modelo impresso 3D do úmero}

O biomodelo do úmero também apresentou diferença visual em relação ao tamanho do osso, já que foi impresso com $80 \%$ do tamanho da peça original. Também produzido em duas partes a região onde se localiza a emenda da peça também ficou aparente. Características anatômicas como tuberosidade deltoide, tubérculo maior, menor e intermédio, cabeça e colo umeral, sulcos intertuberculares, tróclea, fossa do olecrano apresentam-se bem definidas no modelo impresso. 0 forame nutrício não foi demonstrado no modelo impresso (Figura 7,8, 9 e 10).

Figura 7: Biomodelo impresso em 3D do úmero equino, vista cauda $(A)$ e vista lateral $(B)$

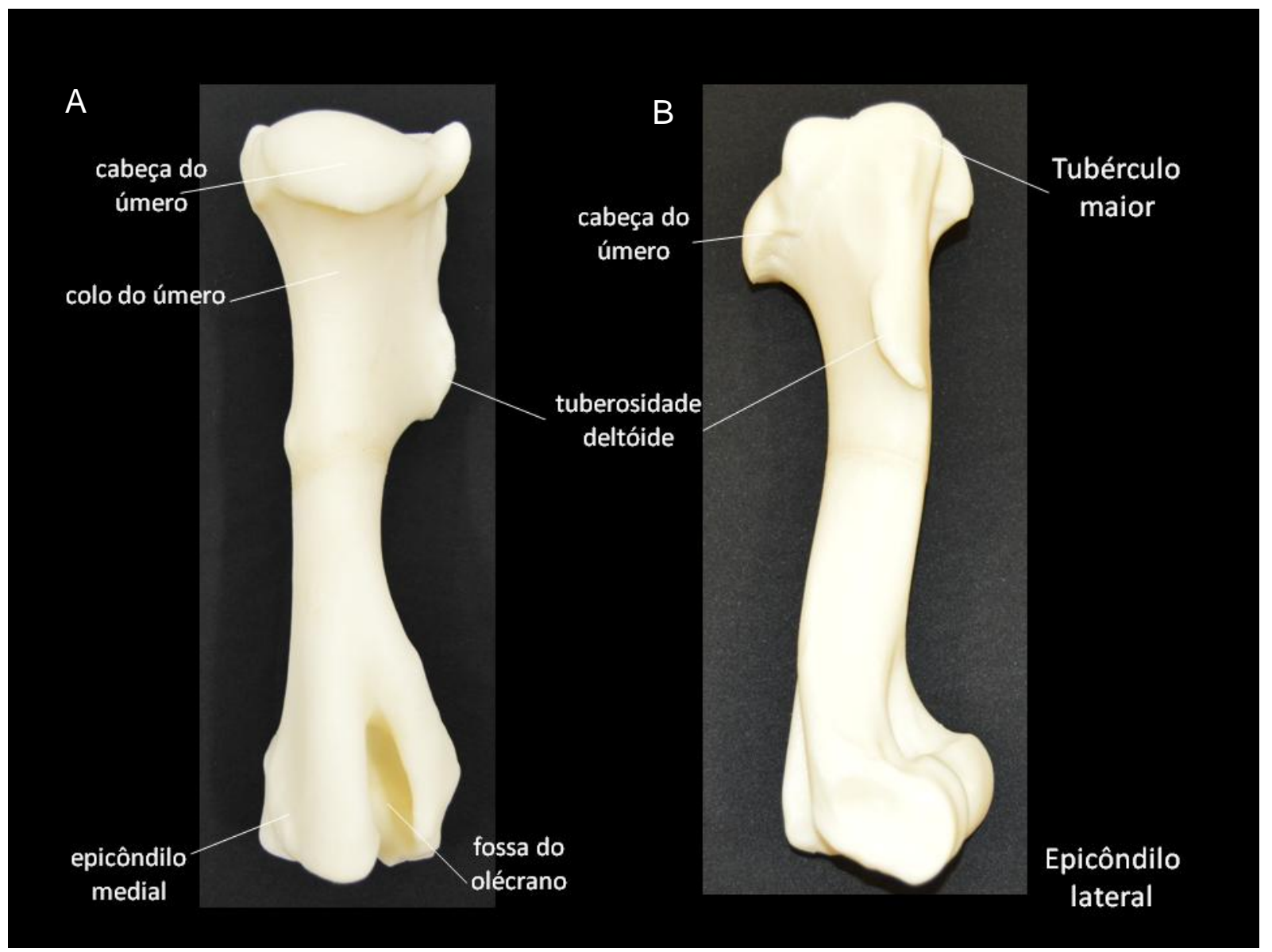

(REIS, 2018) 
Figura 8: Biomodelo impresso em 3D do da extremidade proximal úmero equino $(A)$ e úmero equino (B), vista cranial

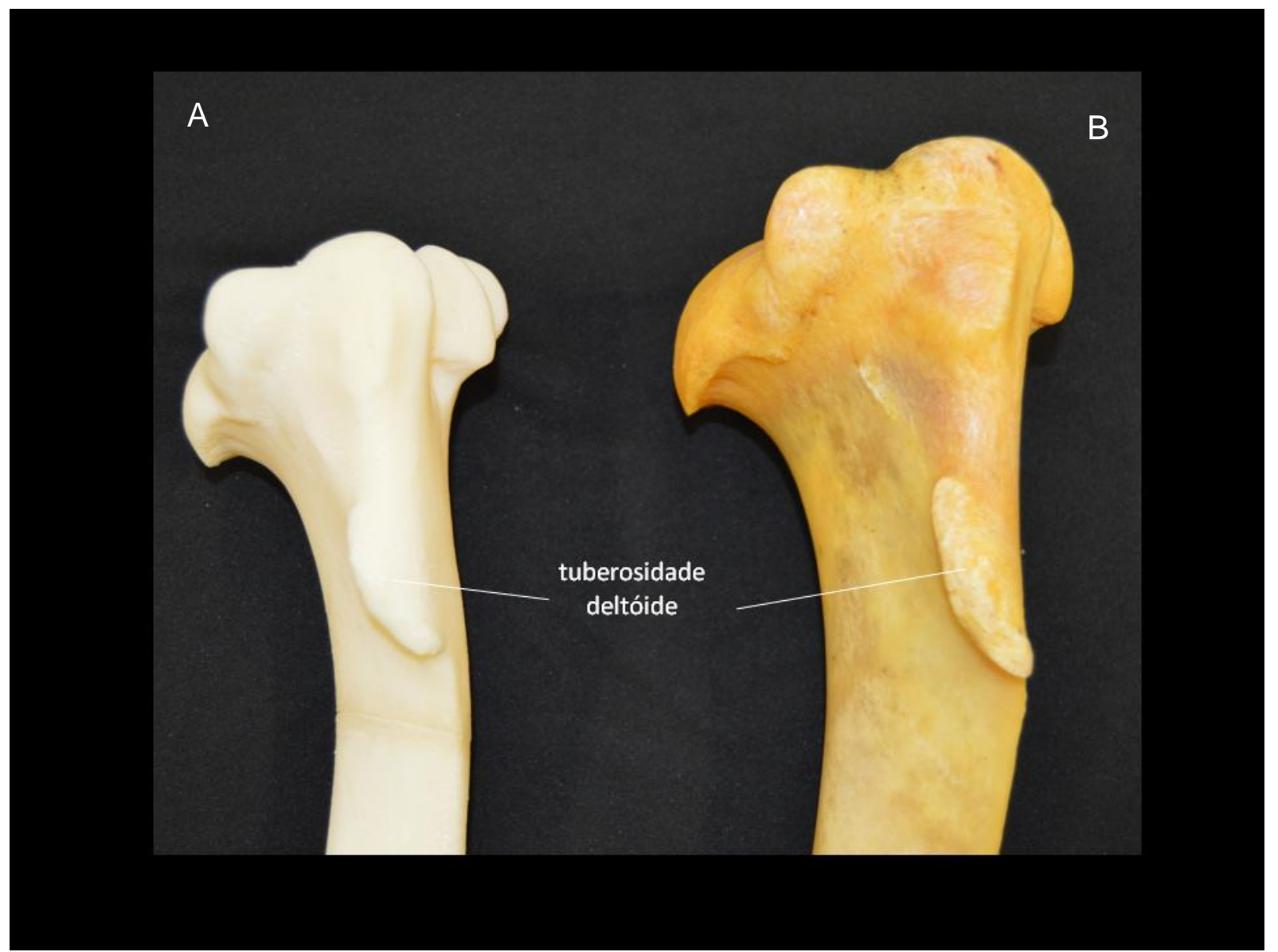

(REIS, 2018) 
Figura 9: Biomodelo impresso em 3D do da extremidade distal úmero equino $(A)$ e úmero equino $(B)$

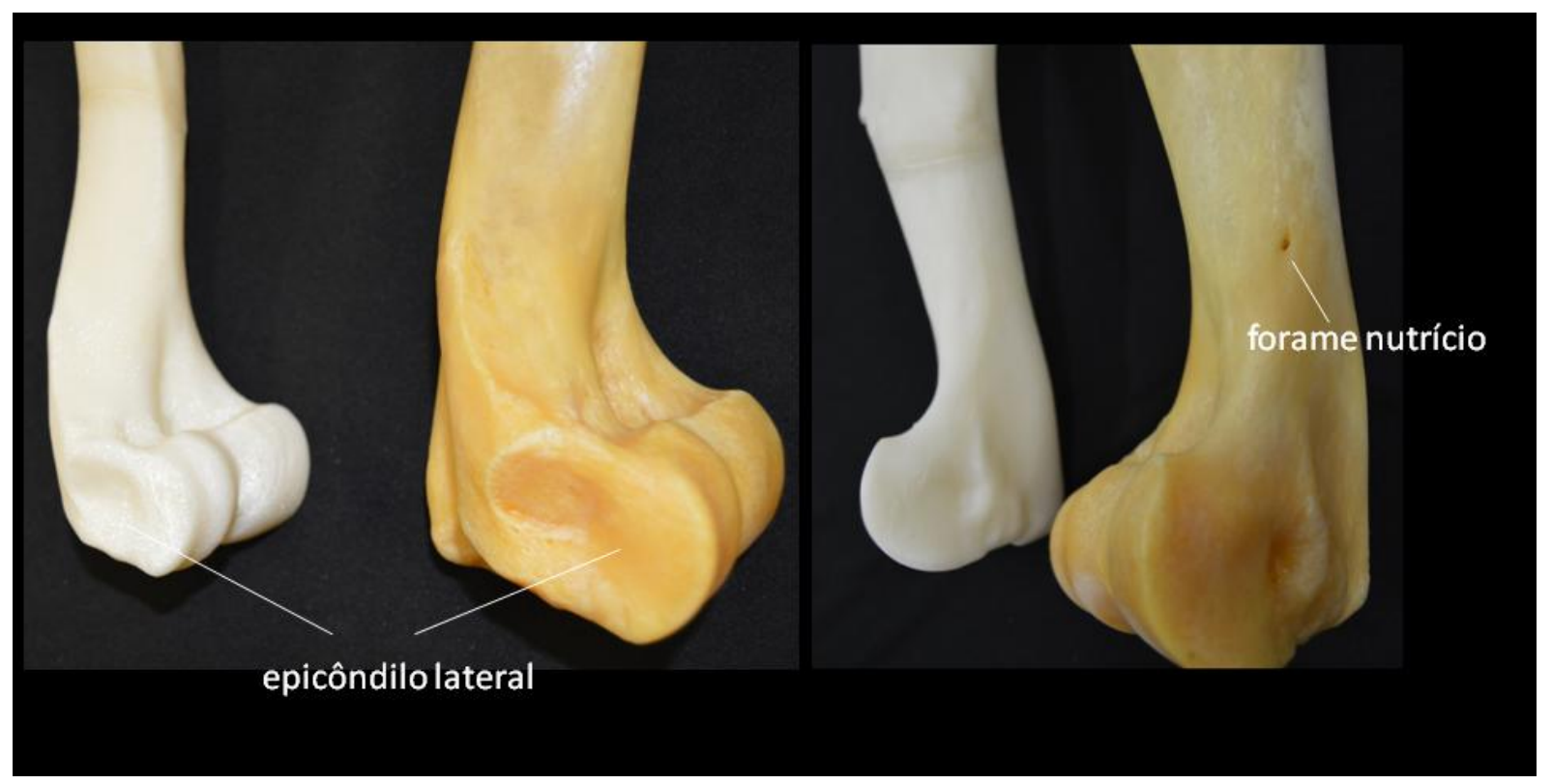

(REIS, 2018)

Figura 10: Biomodelo impresso em 3D do da extremidade distal equino, vista caudal

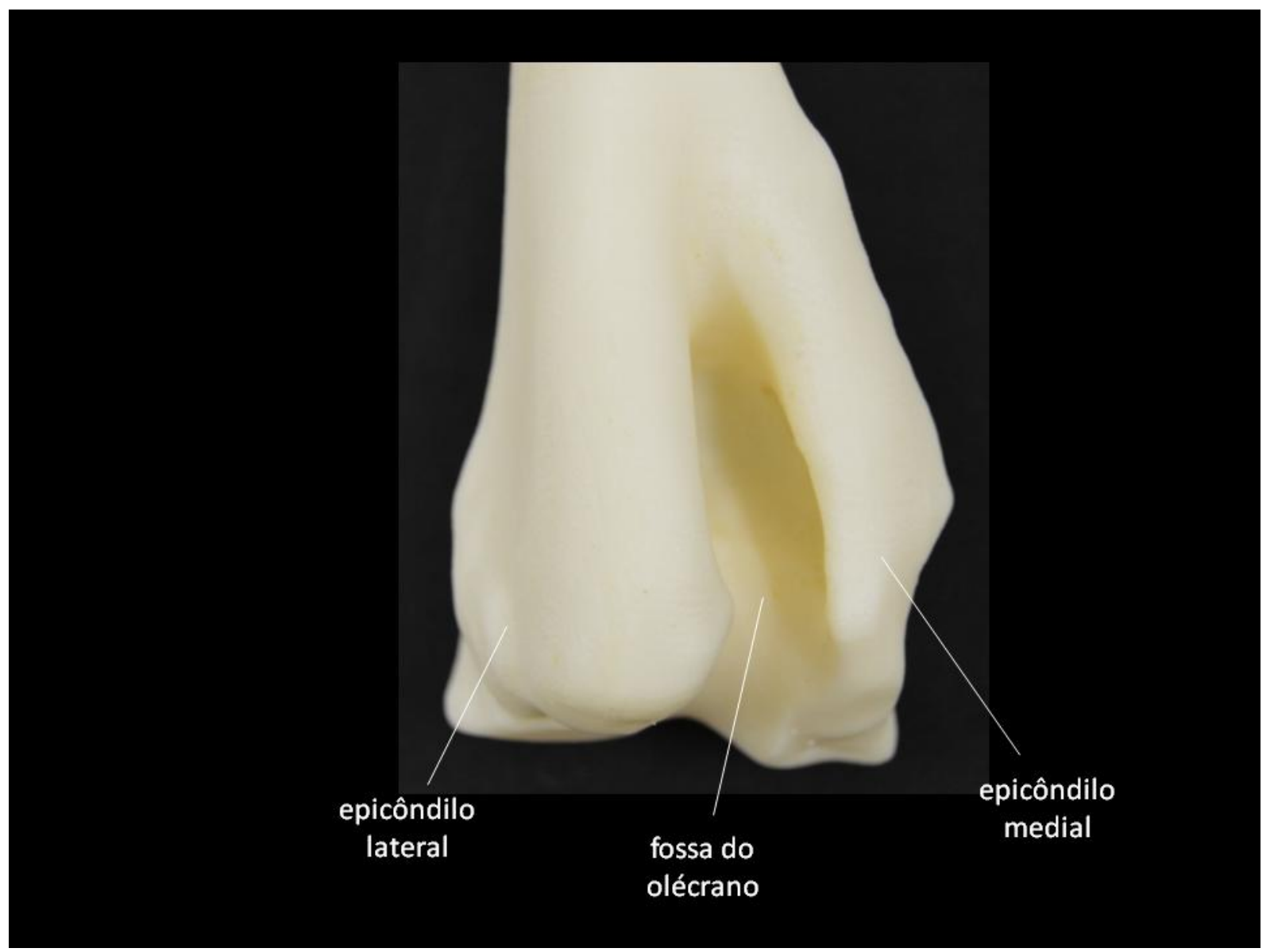

(REIS, 2018) 


\subsubsection{Características anatômicas do modelo impresso 3D do rádio e ulna}

O modelo impresso tridimensional do rádio e da ulna também apresentou diferença visual em relação ao tamanho do osso, já que foi impresso com $80 \%$ do tamanho da peça original. Também produzido em duas partes a região onde se localiza a emenda foi visibilizada como uma discreta linha (Figuras 11,12,13 e 14) Características anatômicas como processo ancôneo, incisura troclear, tuberosidade do olecrano processo estiloide foram identificadas visualmente no biomodelo. Detalhes como o espaço interósseo também foram observados.

Figura 11: Biomodelo impresso em 3D do radio e ulna do equino $(A)$ e osso radio e ulna esquerdos do equino $(B)$, vista lateral.

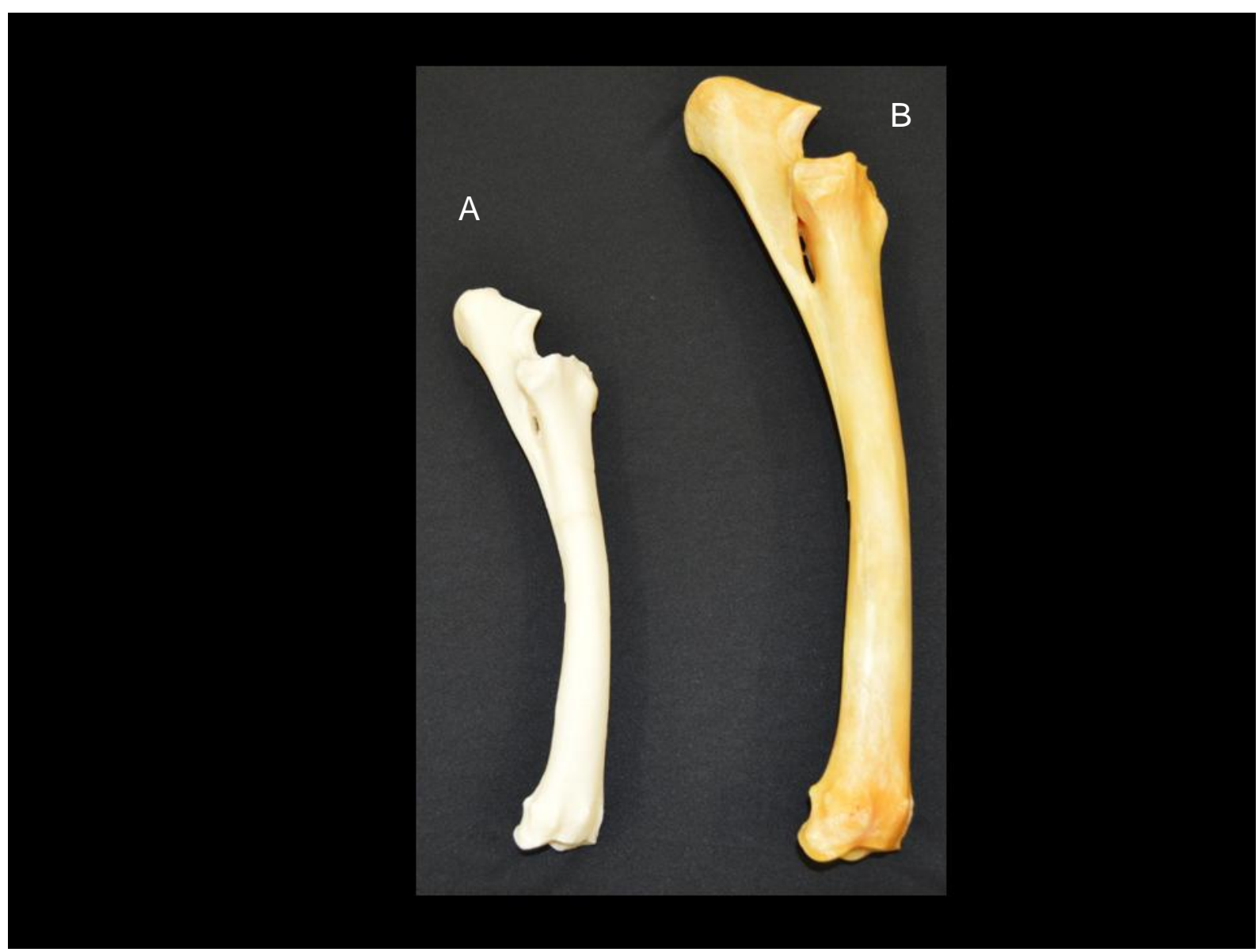

(REIS, 2018) 
Figura 12: Extremidade proximal do biomodelo impresso em 3D do radio e ulna do equino $(A)$ e osso radio e ulna esquerdos do equino $(B)$, vista lateral.

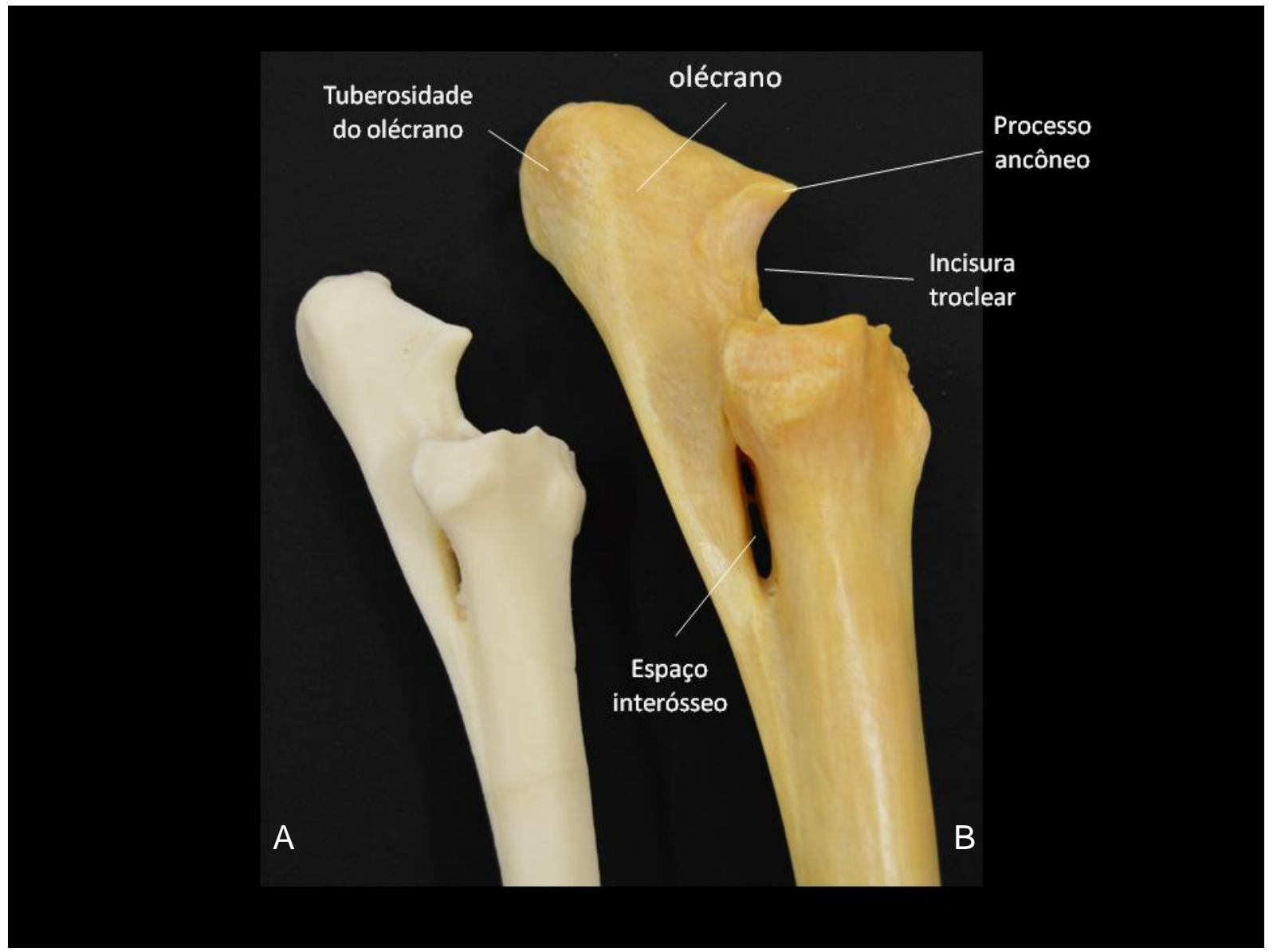

(REIS, 2018) 
Figura 13: Extremidade proximal do biomodelo impresso em 3D do radio e ulna do equino e osso radio e ulna esquerdos do equino, vista cranial $(A)$ e caudal $(B)$

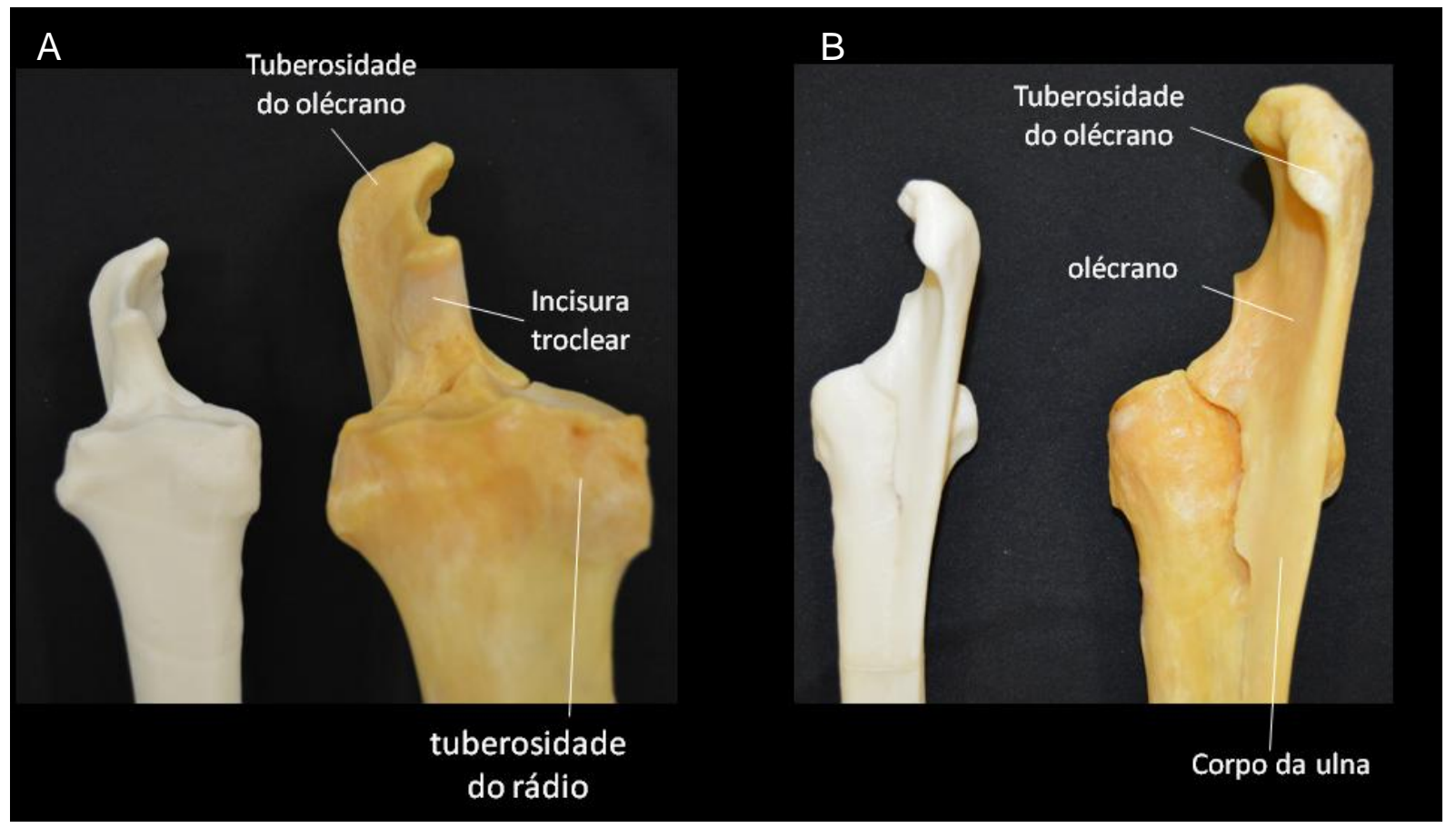

(REIS, 2018)

Figura 14: Extremidade proximal do biomodelo impresso em 3D do radio do equino $(A)$ e osso radio esquerdo do equino (B), vista caudal.

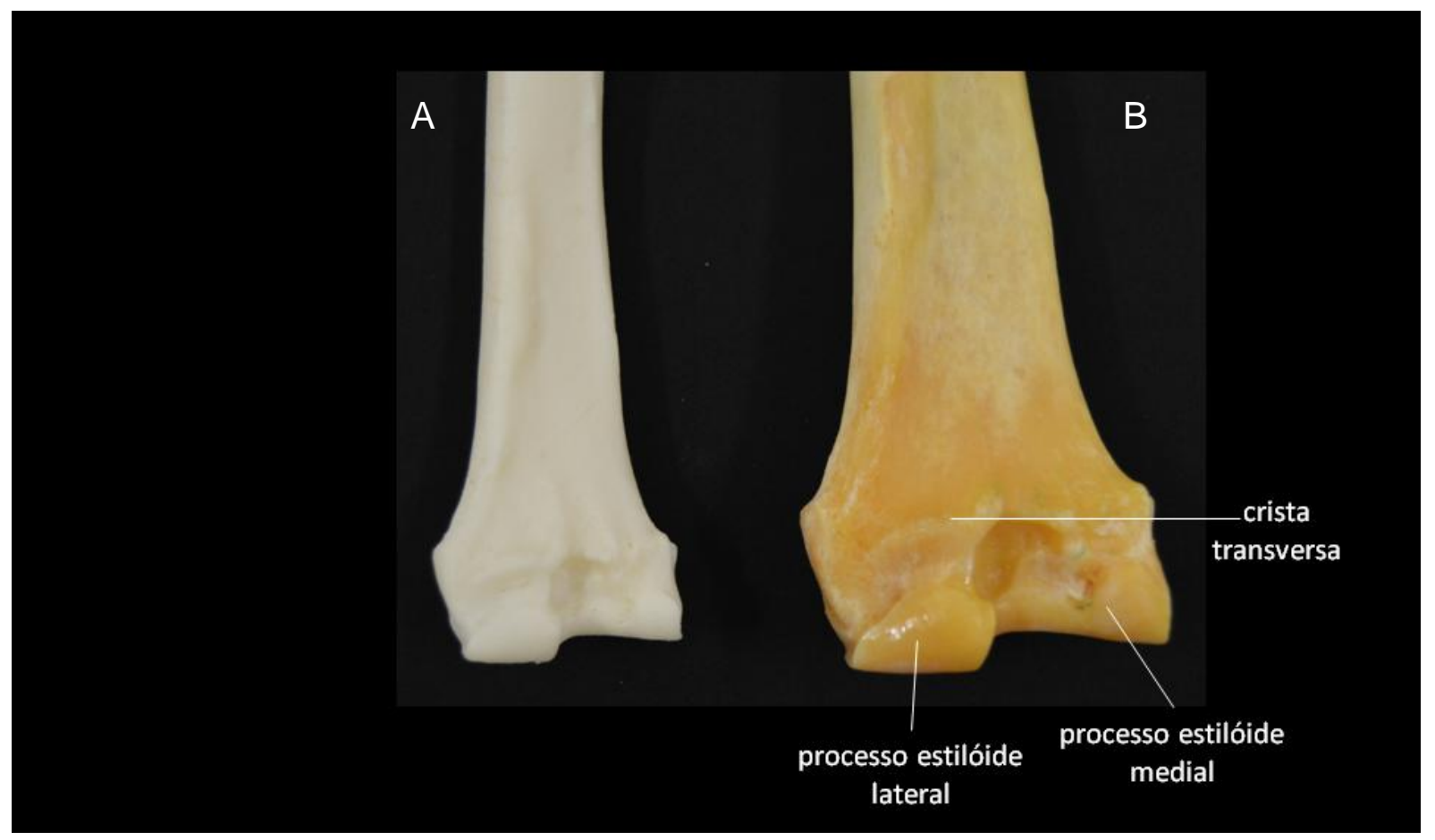

(REIS, 2018) 


\subsubsection{Características anatômicas do modelo impresso 3D dos ossos metacarpianos}

A cópia impressa do II, II e IV metacarpiano foi realizada em escala real. Também produzida em duas partes a região onde se localiza a emenda pode ser visibilizada (Figuras 15, 16 e 17). Detalhes anatômicos como crista da tróclea, assim como e extremidade distal do II metacarpiano foram identificas visualmente. $\mathrm{O}$ forame nutrício não foi demonstrado na peça, no entanto pode ser feito um pequeno furo para representa-lo após a impressão. A extremidade distal do IV metacarpiano não estava presente no osso, não sendo demonstrado, portanto na cópia impressa.

Mesmo sendo produzidas na escala real as medições realizadas nos detalhes anatômicos da peça apresentou valores discretamente maiores, como observados na tabela 7, isso devido ao acabamento dos bordos das peças que se apresentam ligeiramente mais arredondado. 
Figura 15: Biomodelo impresso em 3D dos ossos metacarpianos (A) e ossos metacarpianos esquerdos do equino (B), vista palmar.

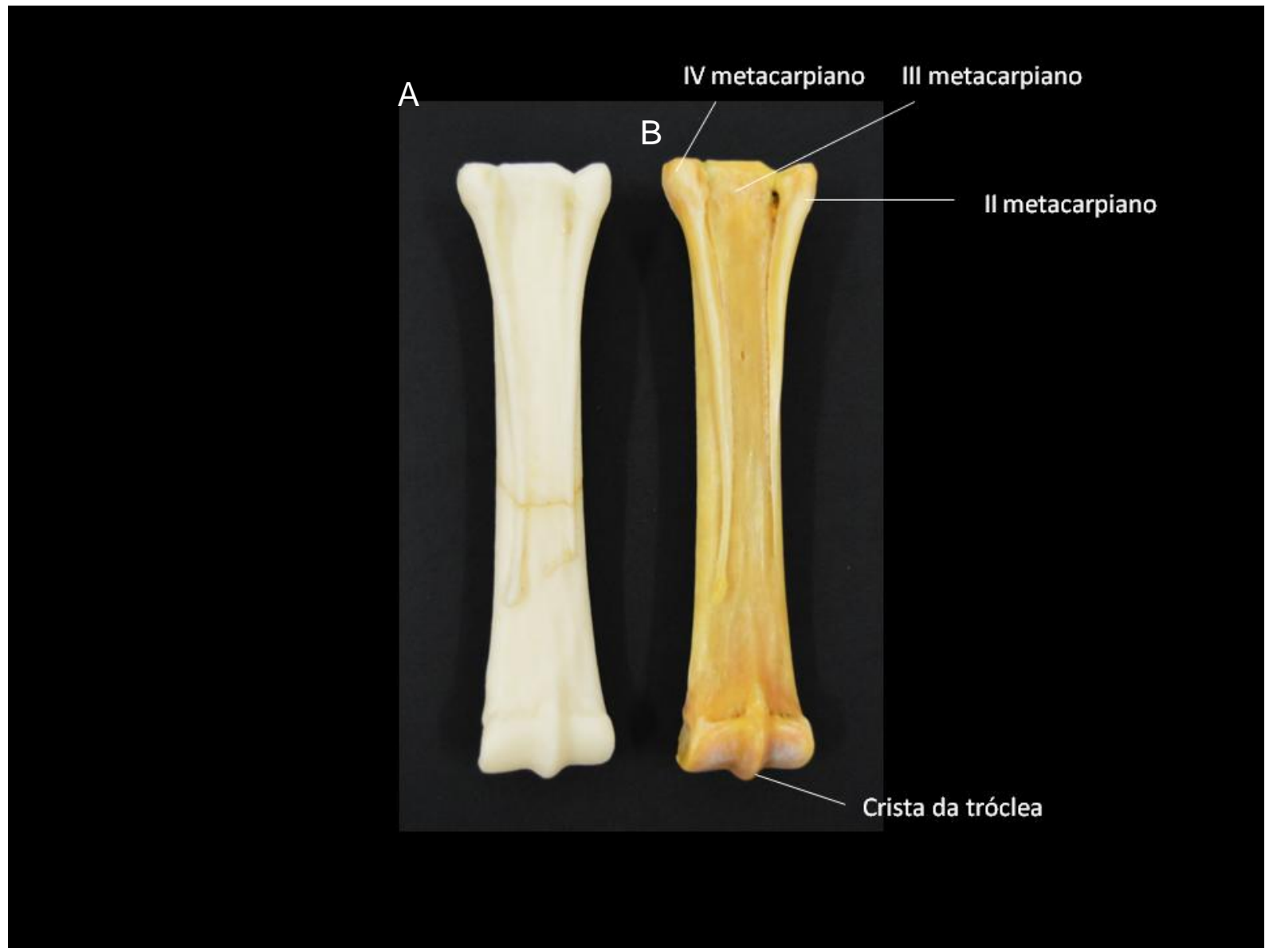

(REIS, 2018)

Figura 16: Extremidade proximal (A) e extremidade distal (B) do biomodelo impresso em 3D dos ossos metacarpianos e ossos metacarpianos esquerdos do equino, vista palmar

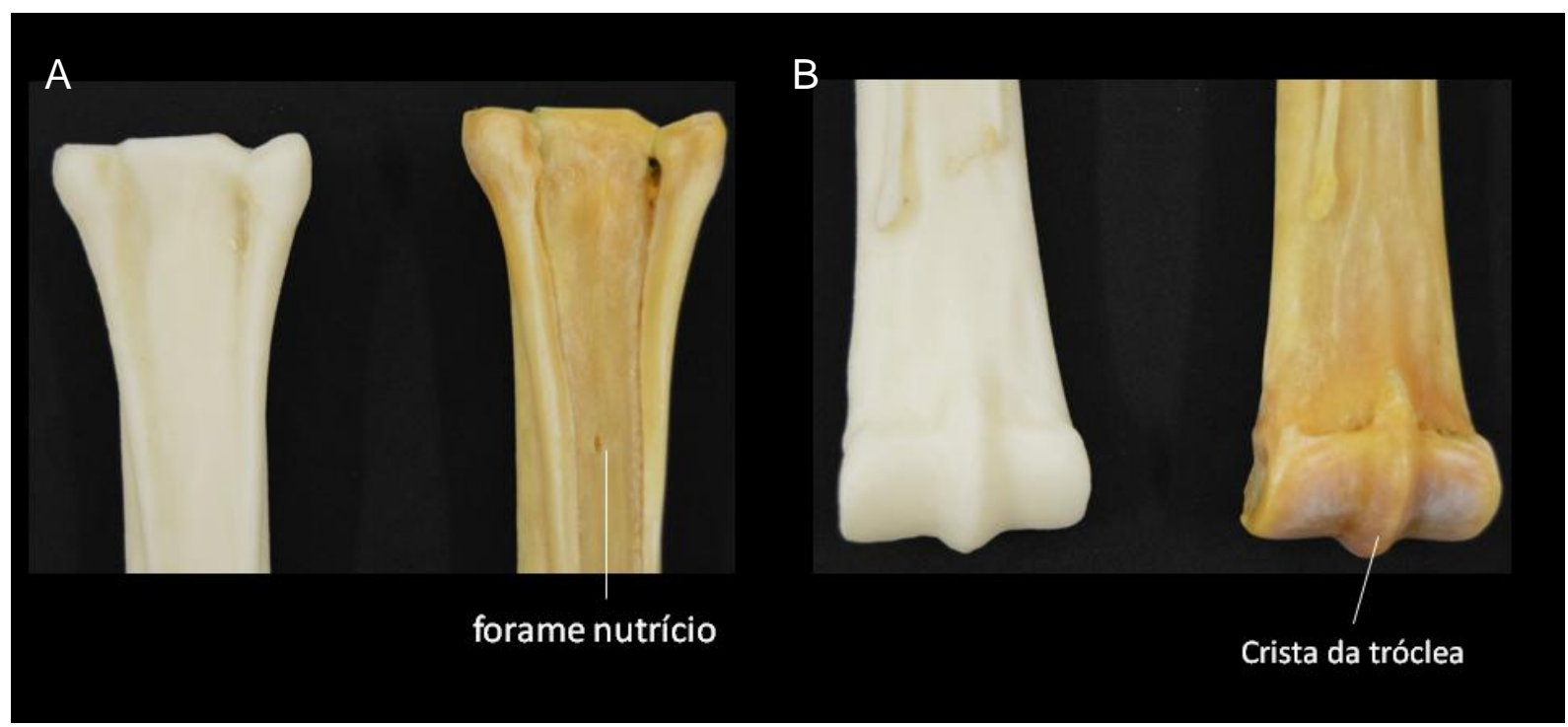

(REIS, 2018) 
Figura 17: Extremidade proximal do biomodelo impresso em 3D dos ossos metacarpianos e ossos metacarpianos esquerdos do equino, vista dorsal

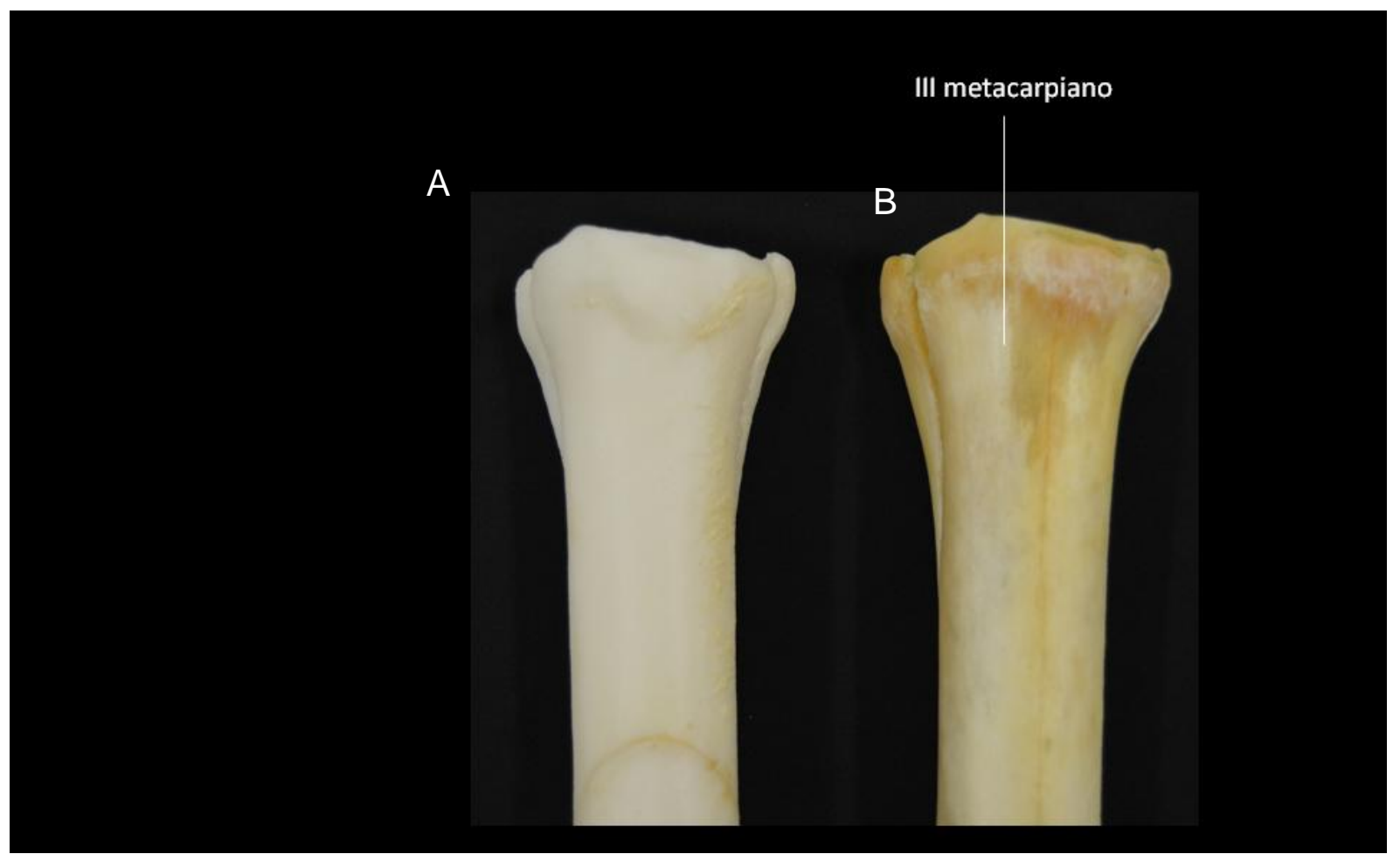

(REIS, 2018)

\subsubsection{Características anatômicas do modelo impresso 3D dos ossos do carpo}

A cópia impressa dos ossos do carpo foi realizada em escala real. Detalhes anatômicos foram identificados visualmente sendo bastante semelhantes.

Produzidas na escala real as medições realizadas nos dois eixos dos ossos e das peças impressas apresentou valores discretamente maiores, como observados na tabela 7 , isso também devido ao acabamento dos bordos das peças que se apresentam ligeiramente mais arredondados (Figuras 18). 
Figura 18: Ossos do carpo do membro torácico esquerdo do equino $(A)$ e seus biomodelos impressos por impressão 3D (B)
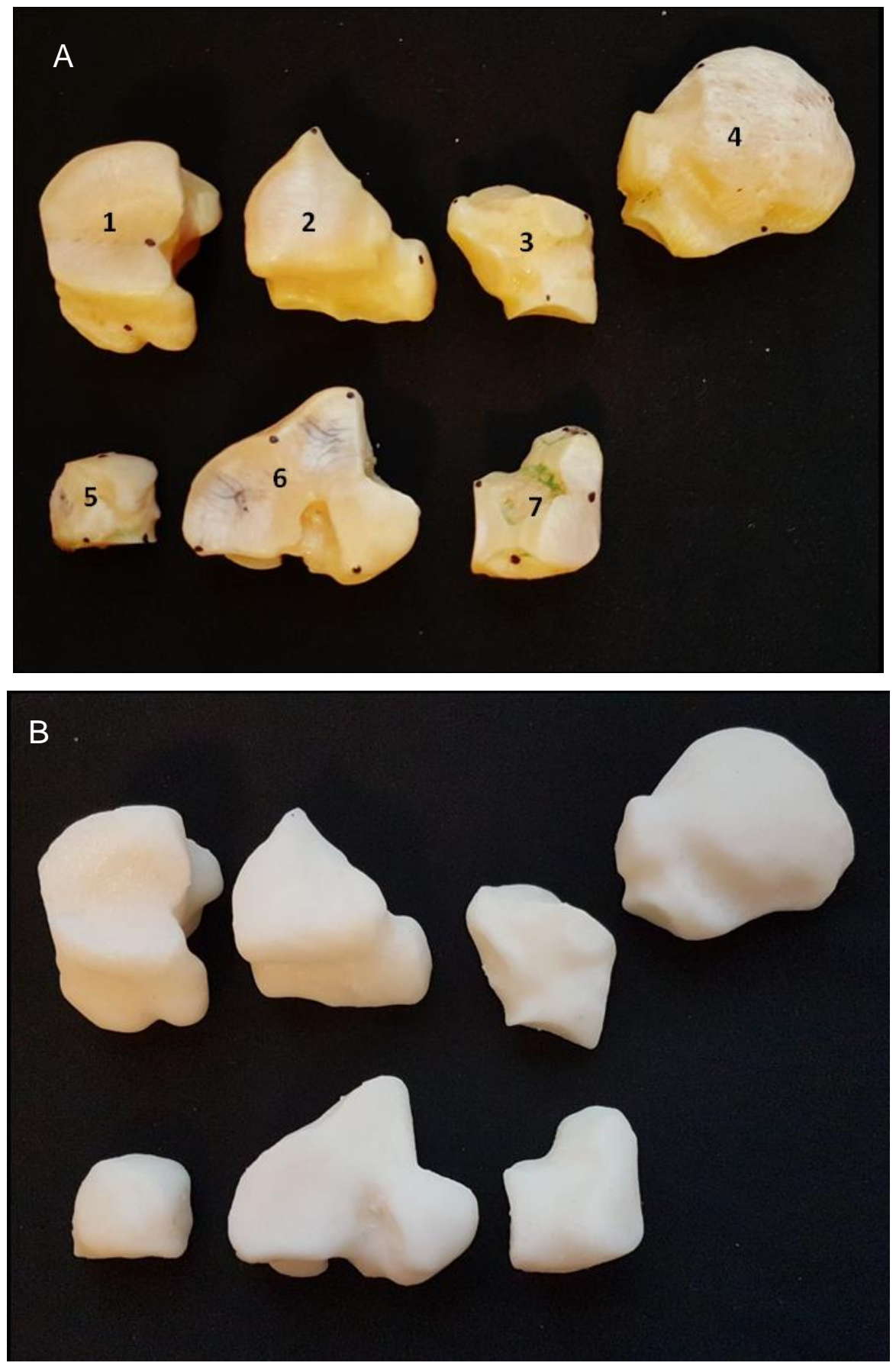

(REIS, 2018)

Legenda: 1- carpo radial, 2-carpo intermédio, 3- carpo ulnar, 4- carpo acessório, 5- segundo cárpico, 6-terceiro cárpico, 7- quarto cárpico. 


\subsubsection{Características anatômicas do modelo impresso 3D das falanges}

A cópia impressa das falanges proximal, média e distal foi realizada em escala real. Detalhes anatômicos foram identificados visualmente sendo bastante semelhantes.

Produzidas na escala real as medições realizadas em alguns detalhes anatômicos das peças impressas apresentaram valores discretamente maiores, como observados na tabela 8 , isso também devido ao acabamento dos bordos das peças que se apresentam ligeiramente mais arredondados. Os forames da falange distal não foram observados no biomodelo (Figuras 19 e 20)

Figura 19: Biomodelo impresso em 3D dos da falange proximal, falange média, falange distal e ossos sesamoide distal (A) e ossos proximal, falange média, falange distal e sesamoide distal esquerdos do equino $(B)$, vista dorsal

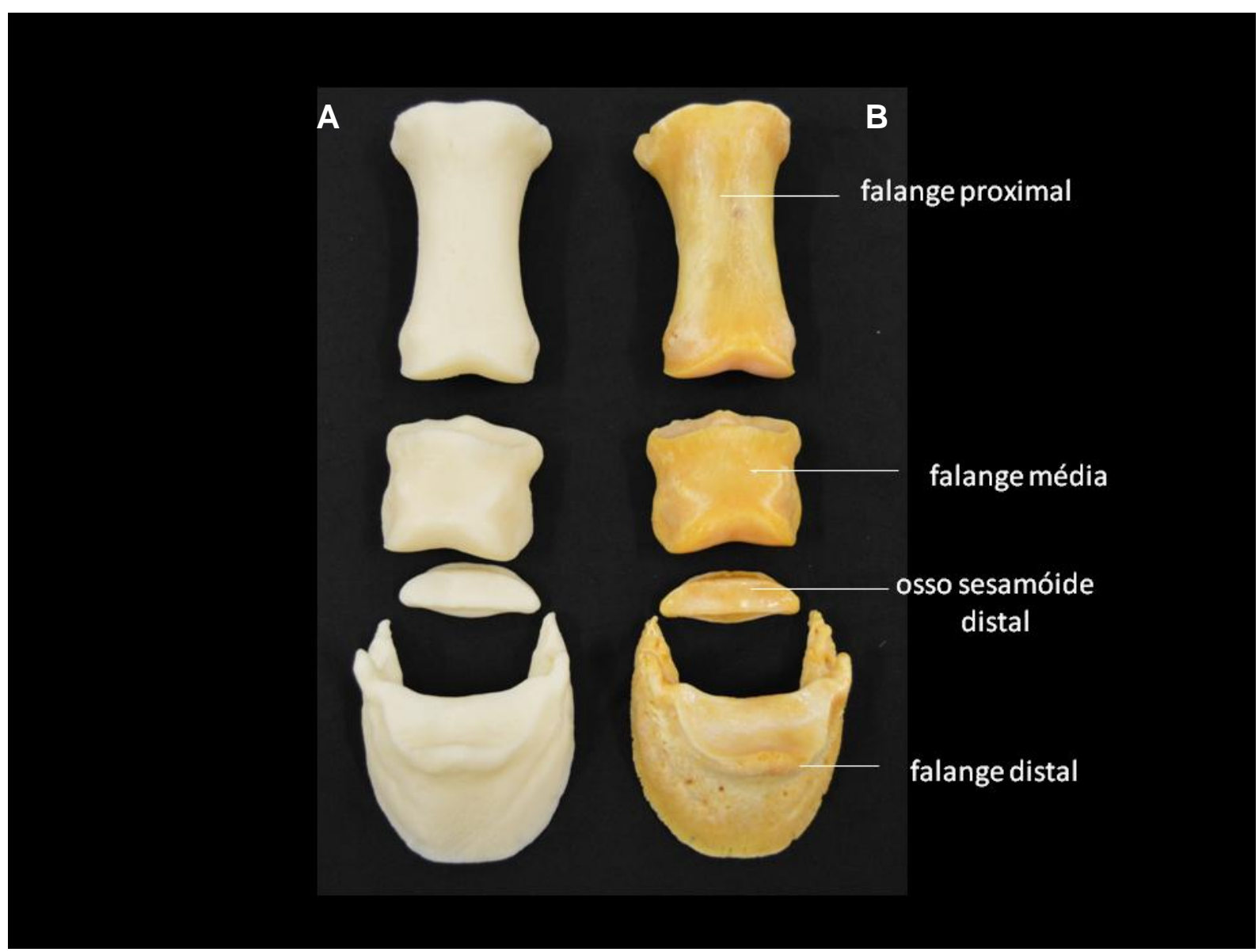

(REIS, 2018) 
Figura 20: Biomodelos impressos em 3D e ossos da falange proximal, falange media na vista dorsal (A) e palmar (B) e falange distal do equino vista dorsal (C).

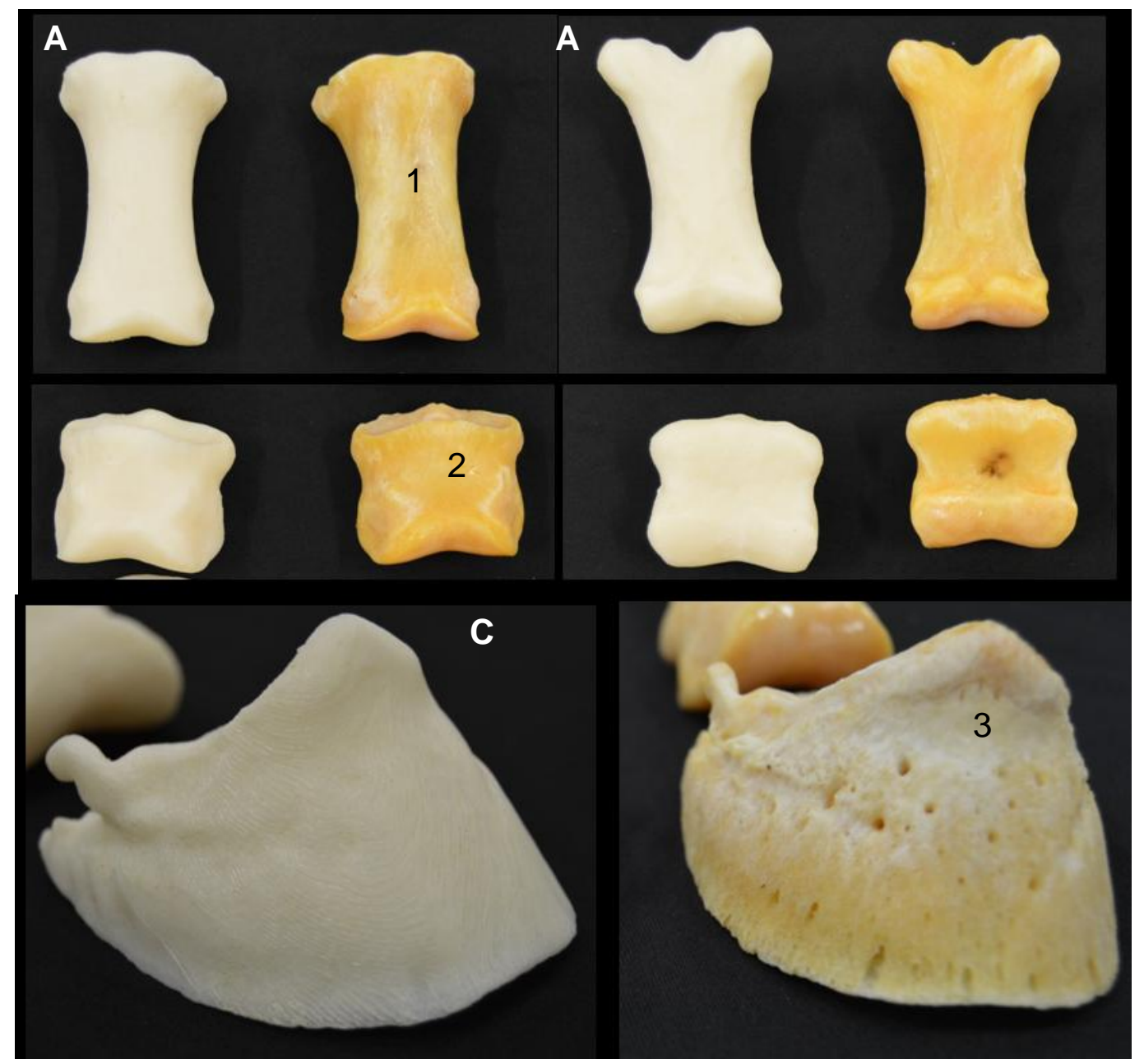

(REIS, 2018)

Legenda: 1- Falange proximal, 2-falange média, 3- falange distal. 


\section{DISCUSSÃO}

Esta pesquisa descreve um método importante para produzir modelos tridimensionais precisos do esqueleto equino usando um scanner manual e uma impressora 3D. Grande parte das características anatômicas originais dos ossos escápula, úmero, rádio e ulna, ossos do carpo, metacarpianos e falanges foram bem identificadas. Esses resultados são consistentes com os relatados anteriormente por outros autores (LI et al., 2017)

As comparações das medidas de algumas estruturas anatômicas realizadas nos ossos e nas cópias, não demonstraram diferença significativa, sugerindo que os modelos 3D podem exibir com precisão quase todas as características anatômicas da peça original podendo ser empregados complemento útil no estudo da anatomia veterinária (Preece et al., 2013).

Os resultados apresentados indicaram as diferenças observadas nas medidas das estruturas anatômicas dos ossos e suas réplicas foram pequenas, portanto a análise osteométrica realizada revelou que não houve diferença significativa na forma e dimensões dos modelos impressos quando comparados aos ossos. Resultados semelhantes foram obtidos em estudos que avaliaram a precisão do sistema de digitalização 3D (LI et al., 2017; THOMAS et al., 2016) As principais diferenças observadas foram em decorrência às dimensões das peças maiores que no momento da impressão foram produzidas em menor escala, como a escápula, o úmero o radio e a ulna. As cópias dos ossos menores como os ossos do carpo apresentaram discretas diferenças nas dimensões por suas margens se apresentarem mais arredondadas, no entanto, esses desvios não levam a quaisquer erros representacionais importantes entre os modelos produzidos e as peças originais.

Os detalhes que não foram bem demonstrados das peças originais às réplicas digitais em 3D e impressas como, por exemplo, os formes nutrícios, também não puderem ser observados em outros trabalhos (LI et al., 2017; THOMAS et al., 2016) mas estes podem ser reproduzidos através do software de edição e serem demonstrados nos modelos digitais. 
As réplicas de osso grandes, que são maiores que a bandeja de impressão podem ser impressas em várias partes e posteriormente unidas não apresentando comprometimento visual das estruturas anatômicas (THOMAS et al., 2016)

Em relação aos custos de produção das peças, conforme descrito em um estudo anterior, os gastos envolvidos na confecção das peças por impressão 3D ainda são menores se comparamos aos custos para produção de peças anatômicas através das técnicas realizadas nos laboratórios de anatomia ou se comprarmos peças plastinadas (HESPEL; WILHITE; HUDSON, 2014). Além dos modelos produzidos apresentarem detalhes anatômicos suficientes para fornecer uma alternativa como material de ensino.

Existem no mercado modelos de plástico de peças anatômicas que muitas vezes são usados em algumas instituições de ensino. Esses modelos são cópias ou moldes produzidos em grande escala usando como base um exemplar anatômico "hipotético" ou "caricatural" onde muitas vezes faltam detalhes anatômicos específicos e importantes. Embora possam ser adequados para alguns fins de ensino eles não são ideais para ensinar anatomia de forma detalhada o que normalmente é exigido aos estudantes de medicina veterinária (HESPEL; WILHITE; HUDSON, 2014).

Após o investimento apropriado em equipamento de digitalização e impressão os custos com a produção dos biomodelos tornam-se relativamente baratos (LI et al., 2017).Nesse trabalho a peça produzida com maior gasto foi 0 úmero e custou aproximadamente $R \$ 264,00$, porém esse valor pode ser ainda bastante reduzido. Esse custo é decorrente ao modelo de impressora utilizado no estudo que opera com material de alto custo, porém atualmente já se encontram no mercado modelos com uma melhor relação custo benefício e com a mesma qualidade de impressão. Essas impressoras 3D, antes presentes somente nas grandes empresas devido seu custo elevado, agora estão mais populares, pois foram desenvolvidas tecnologias que as tornaram bem mais acessíveis podendo ser adquiridas por instituições educacionais como universidades (TAKAGAKI, 2012). Além disso, com a digitalização das peças têm-se os arquivos digitais que podem ser impressos em empresas que realizam o serviço de impressão 3D, sendo uma alternativa útil nos casos onde a instituição não possui uma impressora 3D.

O tempo para produção dos biomodelos também pode ser considerado vantajoso se compararmos ao tempo necessário para a obtenção de ossos através 
do preparo de peças utilizando as técnicas anatômicas. Os biomodelos podem ser produzidos de forma relativamente rápida, a peça que levou maior tempo para ser impressa foi o úmero, com tempo de 14 horas, porém peças com menores dimensões demoraram apenas duas horas para serem impressas. Podemos considerar também o curto tempo para a digitalização, com varreduras das peças durando em torno de 50 minutos cada, sendo necessário um breve treinamento operacional para o uso do scanner 3D.

Devido aos biomodelos serem produzidos a partir de um material termoplástico, e com peso bem mais leve que os ossos o seu uso como material didático não fica restrito somente nos laboratórios de anatomia, podendo ser usado também em outros locais, como bibliotecas e salas de aula (WEN, 2016). A réplica de maior peso foi o úmero, pesando 148 gramas, o úmero do equino usado na digitalização pesou 763 gramas, ou seja, o biomodelo apresentou um peso cinco vezes menor que o peso do osso podendo ser manuseado mais facilmente pelo o aluno durante as horas de estudo nos laboratórios de anatomia.

A digitalização e impressão 3D também podem ser utilizadas para reprodução de espécies de animais raras ou que estejam em extinção, muitas vezes inacessíveis para fins educacionais, produzindo cópias dos esqueletos desses animais que podem ser utilizados em estudos sem o receio de ocorrer avaria na peça, pois caso ocorra basta realizar uma nova impressão, estimulando e incrementando o estudo de anatomia desses animais (THOMAS et al., 2016)

Essa tecnologia também pode ser útil para a pesquisa permitindo que alguns profissionais produzam modelos específicos para um determinado estudo, por exemplo, confeccionado modelos anatômico para discussão de novas estratégicas cirúrgicas.

Outra ferramenta de estudo que pode ser bastante é útil é o banco de dados das imagens que foram digitalizadas. Essas imagens podem ser aplicadas de forma interativa nas salas de aulas, e também serem fonte de material para a criação de sites e aplicativos para smartphones onde o objetivo seja o aprendizado da anatomia. 


\subsection{SUGESTÕES PARA TRABALHOS FUTUROS}

Para validar o uso de biomodelos com impressões 3D como uma ferramenta de aprendizagem alternativa dos alunos, devem ser realizados estudos com alunos de graduação que envolva essas peças do esqueleto esquino e suas réplicas na disciplina de anatomia, envolvendo esses modelos nas aulas do laboratório de anatomia. Avaliando nesses testes não somente a aquisição do conhecimento do aluno com o uso de biomodelos, como também a retenção desse conhecimento. 


\section{CONCLUSÕES}

Este estudo apresenta um projeto inovador e com alto nível de desenvolvimento tecnológico no sentido de criar um método para a fabricação rápida de modelos impressos tridimensionalmente de ossos usando tecnologias de digitalização 3D e impressão 3D. A precisão e confiabilidade dos modelos impressos confirmado pela análise visual das características anatômicas, medições das estruturas e suas comparações com os ossos. Assim, mediante estudos futuros que evolvam testes com os alunos nas aulas de anatomia veterinária, os modelos impressos em 3D podem ser complementares e servir como alternativas confiáveis no estudo da anatomia veterinária. 


\section{REFERÊNCIAS}

ASHDOWN, R. R.; DONE, S. H. Atlas colorido de Anatomia veterinária de Equinos. 2.ed. Rio de Janeiro: Elseiver, 2012. 272p.

BOYD, Sharon; CLARKSON, Eoghan; MATHER, Brian. Learning in the third dimension. Veterinary Record, [s.I], v. 176, p.1-2, abr. 2015.

BRASIL. Lei no 11.794, 8 de outubro de 2008. Regulamenta o inciso VII do $\S 1^{\circ}$ do art.225 da Constituição Federal, estabelecendo procedimentos para o uso cientifico de animais, revoga a Lei ํㅜ 6.638, de 8 de maio de 1979; e dá outras providências, Diário Oficial da União. Brasília, DF, 9 out 2008. Seção 1, p.1-4

CHEN, Shi et al. The role of three-dimensional printed models of skull in anatomy education: a randomized controlled trail. Scientific Reports, [s.I.], v. 7, n. 1, p.1-11, 3 abr. 2017. Springer Nature. http://dx.doi.org/10.1038/s41598-017-00647-1.

DRAKE, Richard L.; PAWLINA, Wojciech. An Addition to the Neighborhood: 3D Printed Anatomy Teaching Resources.Anatomical Sciences Education, [s.I], n. 7, p.419-419, nov. 2014

FElJÓ, Anamaria Gonçalves dos Santos; BRAGA, Luisa Maria Gomes de Macedo; PITREZ, Paulo Márcio Condessa. Animais da Pesquisa e no Ensino - Aspectos éticos e técnicos. Porto Alegre: EDIPUCRS, 2010. 421 p.

GEBARA, Rosangela Ribeiro. Métodos substitutivos ao uso prejudicial de animais no ensino médico veterinário: uma análise da realidade brasileira por meio da percepção do estudante. 2015. 206 f. Dissertação (Mestrado) - Curso de Medicina Veterinária, Cirurgia, Universidade de São Paulo, São Paulo, 2015.

GRANDE NETO, Newton Salvador. Utilização de material alternativo para a obtenção e caracterização de biomodelos, por meio da técnica de impressão 
3dprinter. 2016. 56 f. Dissertação (Mestrado) - Curso de Faculdade de Engenharia, Universidade Estadual Paulista, Ilha Solteira, 2016.

Disponívelem:<http://repositorio.unesp.br/bitstream/handle/11449/137869/grandenet o_ns_me_ilha.pdf?sequence=3>. Acesso em: 01 maio 2016.

HESPEL, Adrien-maxence; WILHITE, Ray; HUDSON, Judith. Invited reviewapplications for $3 \mathrm{~d}$ printers in veterinary medicine. Vet Radiol Ultrasound,, [s.I], v. 0, n. 0, p.1-12, 2014.

KALINKE, Marco Aurélio. Para não ser um professor do século passado. Curitiba: Gráfica Expoente, 1999.

KÖNIG, H. E.; LIEBICH, H. G. Aparelho locomotor. In: Anatomia dos animais domésticos. São Paulo: Artmed, 2002. p. 252-263.

LI, Fangzheng et al. Production of accurate skeletal models of domestic animals using three-dimensional scanning and printing technology. Anatomical Sciences Education, [s.I.], v. 11, n. 1, p.73-80, 15 set. 2017. Wiley-Blackwell. http://dx.doi.org/10.1002/ase.1725.

LIM, Kah Heng Alexander et al; LOO, Zhou Yaw; GOLDIE, Stephen J.; ADAMS, Justin W.; MCMENAMIN, Paul G. Use of 3D Printed Models in Medical Education: A randomized Control Tria Comparing 3D Prints Versus Cadaveric Materials for Learning External Cardiac Anatomy. Anatomical Sciences Education, [s.l], v. 9, n. 1, p.231-221, maio 2015.

MOREIRA, Rui Miguel Dias. Conceção de um sistema de medição sem contacto da temperatura do polímero à saída do bico de uma impressora 3D FDM. 2016. 98 f. Dissertação (Mestrado) - Curso de Engenharia Mecânica, Universidade do Porto, Porto, 2016.

POPESKO, P. Atlas de anatomia topográfica dos animais domésticos. São Paulo: Manole, 1990. v. III 
PREECE, Daniel et al. "Let's Get Physical": Advantages of a Physical Model Over 3D Computer Models and Textbooks in Learning Imaging Anatomy. Anatomical Sciences Education, [s.I], n. 6, p.216-224, jul. 2013.

SAURA, C. E. Aplicação da prototipagem rápida na melhoria do processo de desenvolvimento de produtos em pequenas e médias empresas. Campinas, 2003. 105 f. Dissertação (Mestrado) - Faculdade de Engenharia Mecânica, Universidade Estadual de Campinas.

SEARS, N. A.; SESHADRI, D. R.; DHAVALIKAR, P. S.; COSGRIFF-HERNANDEZ, E. A review of three-dimensional printing in tissue engineering. Tissue Engineering. Part B, Reviews, v. 22, p. 298-310. 2016.

SEIXAS, Mone Martins; VIRGENS, João Henrique Araujo; MELO, Stella Maria Barrouin; HERK, Alexander Gerard Steevert van. Consciência na substituição do uso de animais no ensino: aspectos históricos, éticos e de legislação. Revista Brasileira de Direito Animal, [s.I], v. 6, n. 5, p.71-96, jan. 2010. Semestral. Disponível em: <https://portalseer.ufba.br/index.php/RBDA/article/viewFile/11073/7987>. Acesso em: 10 mar. 2017.

SILVA, FÁBIO PINTO DA. Usinagem de espumas de poliuretano e digitalização tridimensional para a fabricação de assentos personalizados para pessoas com deficiência. 2011. 192 f. Tese (doutorado) - curso de engenharia, universidade federal do rio grande do sul, porto alegre, 2011.

SILVA, FRANCISCO DA; ROSADO, VICTOR ORLANDO GAMARRA.

Biomodelagem virtual para diagnóstico e planejamento cirúrgico usando softwares livres. Informática na educação: teoria e prática, porto alegre, V. 17, N. 1, P. 125143, JAN./JUN.2014

SISSON, S.; GROSSMAN, J. D. Músculos do carnívoro. In: GETTY, R. (Ed.). Anatomia dos animais domésticos. 5. ed. Rio de Janeiro: Guanabara Koogan, 1986. v. 2. p. 1436-1436 
TAKAGAKI, Luiz Koiti. Tecnologia de Impressão 3D. Revista de Inovação

Tecnológica, São Paulo, v. 2, n. 2, p.28-40, jul. 2012. Disponível em:

<http://rit.faculdadeflamingo.com.br/ojs/index.php/rit/article/view/54>. Acesso em: 10 maio 2017.

THOMAS, Daniel B. et al. 3D scanning and printing skeletal tissues for anatomy education. Journal Of Anatomy, [s.I.], v. 229, n. 3, p.473-481, 5 maio 2016. Wiley. http://dx.doi.org/10.1111/joa.12484.

WEN, Chao Lung. Homem Virtual (Ser Humano Virtual 3D): A Integração da Computação Gráfica, Impressão 3D e Realidade Virtual para Aprendizado de Anatomia, Fisiologia e Fisiopatologia. Grad+ Revista de Graduação da Usp, S.I., v. 1, n. 1, p.7-16, 05 jul. 2016.

ZURADA, Anna; GIELECKI, Jerzy St.; OSMAN, Nilab; TUBBS, R. Shane; LOUKAS, Marios; BEDI, Neru; NOWAK, Dariusz. The study techniques of Asian, American, and European medical students during gross anatomy and neuroanatomy courses in Poland. Surgical And Radiologic Anatomy, [s.I.], v. 33, n. 2, p.161-169, 24 ago. 2010. Springer Nature. http://dx.doi.org/10.1007/s00276-010-0721 